\title{
The segmental and tonal structure of verb inflection in Babanki
}

\author{
Pius W. Akumbua ${ }^{\mathrm{a}}$, Larry M. Hyman ${ }^{\mathrm{b}} \&$ Roland Kießling ${ }^{\mathrm{c}^{*}}$ \\ aUniversity of Buea - akumbu.pius@ubuea.cm \\ bUniversity of California, Berkeley - hyman@berkeley.edu \\ 'Universität Hamburg - roland.kiessling@uni-hamburg.de
}

\begin{abstract}
In this study we provide a comprehensive phonological and morphological overview of the complex tense-aspect-mood (TAM) system of Babanki, a Grassfields Bantu language of Cameroon. Our emphasis is on the competing inflectional tonal melodies that are assigned to the verb stem. These melodies are determined not only by the multiple past and future tenses, perfective vs. progressive aspect, and indicative vs. imperative, subjunctive, and conditional moods, but also affirmative vs. negative and "conjoint" (CJ) vs. "disjoint" (DJ) verbal marking, which we show to be more thoroughgoing than the better known cases in Eastern and Southern Bantu. The paper concludes with a ranking of the six assigned tonal melodies and fourteen appendices providing all of the relevant tonal paradigms.
\end{abstract}

Keywords: tonal melodies; grammatical tone; verb inflection; tonal paradigms; conjoint; disjoint

\section{Introduction}

The purpose of this paper is to provide a description of tense-aspect-mood marking in Babanki, a Grassfields Bantu language of the Ring subgroup spoken in Western Cameroon (Hyman 1980; Akumbu \& Chibaka 2012). Similar to related Grassfields Bantu languages, we will show that Babanki distinguishes multiple past and future tenses as well as a progressive/non-progressive aspect distinction. Particularly striking is the discovery of a thoroughgoing conjoint-disjoint contrast similar to, but more pervasive than, the CJ/DJ distinctions which have been extensively documented in Narrow Bantu (see the papers in van der Wal \& Hyman 2017 and references cited therein). The various tense aspect markers (TAMs) are expressed through an extensive system of multiple exponence, which may involve pre- and/or post-verbal particles, prefixes and suffixes, and tone. In the following sections we will first present preliminary aspects of Babanki morphology and tonology $(\S 2)$, then describe the seven indicative tenses as they appear in the perfective $(\S 3)$, the progressive $(\S 4)$, and their corresponding negatives $(\S 5)$. We then turn to the imperative, subjunctive, and conditional moods, first presenting their affirmative forms ( $(6)$, then the corresponding negative forms $(\S 7)$. In our conclusion $(\$ 8)$ we present an analysis integrating all of the relevant morphosyntactic features seen to determine the tonal patterns in the preceding sections.

\footnotetext{
* The first author acknowledges the Fulbright Scholar Program for a Fulbright African Research Scholar Grant to the University of California Berkeley (2015-2016) and the Alexander von Humboldt Foundation for a Georg Forster Research Fellowship for Experienced Researchers (2019-2020) which have allowed for greater progress and the present collaboration. Special thanks to two other Kejom Ketinguh speakers: Regina Phubong and Vivian Ba-ah who contributed some of the data, and to Gene Buckley and two anonymous reviewers for helpful comments on the original submission.
} 


\section{Preliminaries}

As indicated, Babanki is a member of the Ring subgroup of Grassfields Bantu, with close relatives such as Kom, Bum and Men in Central Ring, Aghem and Isu in Western Ring, and Lamnso and Babungo in Eastern Ring, among others. Previous work on Babanki includes studies by Hyman (1979a, 1980), Mutaka and Chie (2006), Akumbu (2011, 2015, 2016), Akumbu \& Chibaka (2012) and Chie (2014). Much of this work has centered around the morphology and tone of elements within the noun phrase, as Babanki has a full Bantoid-like noun class system. However, comparative lexical work has included verbs and especially the study of the verb extension system (Akumbu 2015; Hyman 2018). Only recently have we begun to look systematically at the verb inflection system, which we report on here. The current materials were compiled by the first author, a native speaker of Kejom Ketinguh (Babanki Tungo) dialect, which differs from the Kejom Keku (Big Babanki) dialect in only minor ways. ${ }^{1}$ In order to facilitate the discussion of the tenseaspect system, a few preliminaries are in order.

First, since we will present sentences with both a subject and an object, it is important to note that Babanki is an SVO language, where the object, whether nominal or pronominal, follows the verb. Second, as seen in the following table, there is a subject-verb agreement marker (SM) which differs from subject pronouns (Pro) and is most visible in classes which have a Co shape, since the schwa that marks other classes may completely fuse with a neighboring vowel. ${ }^{2}$

Table 1: Babanki subject pronouns and concords

$\begin{array}{cccccc}\text { class } & \text { Pro } & \text { SM } & \text { class } & \text { Pro } & \text { SM } \\ 1 & \text { yò } & \varnothing & 7 & \text { ká } & \text { ká } \\ 2 & \text { và } & \text { á } & 8 & \text { vá } & \text { á } \\ 3 & \text { ghá } & \text { á } & 9 & \text { zà } & \varnothing \\ 5 & \text { zá } & \text { à } & 10 & \text { sá } & \text { sá } \\ 6 & \text { ghá } & \text { á } & 13 & \text { tá } & \text { tá } \\ \text { 6a } & \text { mà } & \varnothing & 19 & \text { fá } & \text { fá }\end{array}$

An overt class 19 subject concord marker (SM) fă is seen in the following example, agreeing with fànyín 'bird':

$$
\begin{array}{lllll}
\text { fà-nyín fá } & \text { n-lám } & \text { lí } & \text { kò-báyn } \\
\text { 19-bird } & \text { 19.PFV.P3 } & \text { N-cook P3 } & \text { 7-fufu }
\end{array}
$$

'A bird cooked fufu.'

As will be further discussed when we consider the different TAMs, in the above disjoint (DJ) form, the distant past (P3) is marked by a schwa which fuses with $f^{\prime}$, as well as by the prefix $n$ - and the post-verbal particle $l i$. As we will see, a perfective morpheme /á/ also occurs between the SM and the verb, but fuses with fá as well. In other tenses preverbal particles can have the shape CV, e.g. general past (P2)/tว̀/. While (1) clearly shows a SM, we will generally cite sentences where the subject is the name búy 'Bung' belonging to class 1 , which does not have a SM.

\footnotetext{
${ }^{1}$ Only a few lexical items are different in the two dialects (examples to the left are from Kejom Keku while those to the right are from Kejom Ketinguh): fàmváy vs. túbù 'jigger'; kàbwín vs. jì 'road'; wúg vs. fàlàm 'fishing net'. There are also a few sound differences: kàbònà vs. kàbòlà 'calabash'; kàbwá' vs. kàbyá' 'half'; wàn vs. wàyn 'child'; kànshìf vs. kànfyìf 'blindness'.

${ }^{2}$ We have indicated the standard Bantu numbering since the noun classes that exist in Babanki correspond to those reconstructed in Proto-Bantu (Meeussen 1967). In transcribing Babanki forms, we recognize 26 consonants [b, t, d, k, g, ?, m, n, ny, y, f, v, s, z, sh, zh, gh, pf, bv, ts, dz, ch, j, l, w, and y] and 8 vowels [i, i, u, u, e, o, ə, a]. Vowel length is not underlyingly contrastive in Babanki. We follow IPA transcription except that $\left[\int, 3, \mathrm{n}, \mathrm{\gamma}, \mathrm{j}\right]$ are transcribed [sh, zh, ny, gh y], respectively, and [u] represents IPA [w].
} 
Turning to the structure of the verb, the verb root may have the shape CV or CVC, while the verb stem can be $\mathrm{CV}, \mathrm{CVC}, \mathrm{CVCV}$, or CVCCV. The bisyllabic stem forms derive diachronically from a root + suffix, which may be either identifiable as a "verb extension" (e.g. causative, pluractional), or can be lexically frozen on the root. In Table 2, the verbs cited in our study are presented in their root, stem, infinitive, and imperative forms.

Table 2: Babanki verbs cited in this study

\begin{tabular}{|c|c|c|c|c|c|c|}
\hline root tone & root & stem & infinitive & imperative & gloss & stem shape \\
\hline $\mathrm{H}$ & zhí & zhí & á- ${ }^{\downarrow} z h \dot{t}$ & zhí & 'eat' & $\mathrm{CV}$ \\
\hline $\mathrm{H}$ & lám & lám & á-`lám & lám & 'cook' & $\mathrm{CVC}$ \\
\hline $\mathrm{H}$ & shí & shító & ó- ${ }^{\downarrow}$ shító & shító & 'collect' & $\mathrm{CVCV}$ \\
\hline $\mathrm{H}$ & són & sə́ytə́ & ว́-`sə́ntว́ & sə́ntว́ & 'sift' & $\mathrm{CVCCV}$ \\
\hline L & lè & lè & ว́-lè & lèé & 'lose' & $\mathrm{CV}$ \\
\hline $\mathrm{L}$ & kùm & kùm & á-kùm & kùmó & 'touch' & $\mathrm{CVC}$ \\
\hline $\mathrm{L}$ & shì & shìsò & ว́-shìs & shìsó & 'remove' & CVCV \\
\hline $\mathrm{L}$ & lìm & lìmsò & ว́-lìmsà & lìmsá & 'heat' & CVCCV \\
\hline
\end{tabular}

As seen, verb roots contrast high (H) and low (L) tone, marked with an acute (') vs. grave (') accent. Suffixes are underlyingly toneless and take the same tone as the root unless a conflicting suffix tone is assigned by a specific TAM. In the examples sántá 'sift' has the pluractional suffix -tz (cf. sáy 'sift') while lìmsà 'heat' has the causative suffix - $s$ ( $\mathrm{cf}$. lim 'be hot'). Analyzing these (and more complex) forms requires further discussion of the tone system. The underlying $/ \mathrm{H} /$ and $/ \mathrm{L} /$ are subject to various tone rules which produce additional surface contrasts. The infinitive prefix $\dot{\partial}$ - in Table 2 causes a $\mathrm{H}$ tone root to be downstepped, marked by the down arrow $\left({ }^{\downarrow}\right)$. We attribute this to a floating L which follows the schwa, i.e. $/ 2 \%$, and which also prevents the $\mathrm{H}$ of the prefix from spreading onto a $\mathrm{L}$ verb root. In addition, there is a third, derived surface-contrastive mid (M) pitch height, marked by a macron $\left(^{-}\right)$. Falling HL $\left(^{\wedge}\right)$ and rising LH $(\checkmark)$ tones also occur, but are much more restricted. In the data to be presented they only occur on preverbal TAM particles and not on the verb stem itself. ${ }^{3} \mathrm{M}$ tones derive from two sources (cf. Hyman 1979; Akumbu 2019), illustrated in the following examples involving the $\mathrm{H}$ and $\mathrm{L}$ tone verb roots /lám/ 'cook' and /kùm/ 'touch':
a. lám kābáyn
b. kùmó kə̄báyn
a. Búy tà làm kābáyn
b. Bún tà kùm kàbáyn
'Bung cooked fufu.'
'Bung touched fufu.'
(P2 conjoint)

'cook fufu!'

'touch fufu!' (imperative)

In (2) we see that a noun class prefix, here /kò-/, raises to $M$ between two $H$ tones, the first of which is a $H$ suffix on the verb (see below). As was also seen in Table 2, the L tone verb in (2b) has acquired an epenthetic schwa to avoid the rising tone that would otherwise result from combining the root $\mathrm{L}$ with the $\mathrm{H}$ suffix tone of the imperative (*küm). Such register raising of L to M occurs only in TAMs which assign a $\mathrm{H}$ suffix to the verb.

The second source seen in (3a) owes its existence to a rule of L tone spreading (LTS), here applying from the P2 TAM marker/tà/ onto the H verb root /lám/ 'cook'. Since the language does not tolerate rising tones on lexical morphemes, the result in this case is to shift the $\mathrm{H}$ onto the prefix, producing an intermediate HL falling tone (làm kâbáyn). The resulting L-HL-H sequence is then converted to L-M-H (cf. Hyman

\footnotetext{
${ }^{3}$ The only time a verb can have a HL tone is when it occurs clause-finally in certain non-indicative moods such as the hortative, e.g. yúwù kûm 'let's touch!' (see §6). Contour tones are also rare on nouns, occurring only on the first stem syllable, mostly limited to borrowings, lexicalized compounds, and reduplications, e.g. lâm 'lamp', sǒ 'saw', ànkǔnyàm 'pig', bûtbùt 'deaf (mute) person', fândzǒnzdò 'bird (sp.)'.
} 
1979; Akumbu 2019). Although beyond the scope of this paper, whether LTS will apply onto a monosyllabic verb depends on what follows it:
a. LTS applies
with object: Búy tò làm kàtò?
Bún tà làm nántô
Bún tò làm nò mbàsò
Bún tò làm ghó
Bún tà làm kābáyn
'Bung cooked the fufu.'
'Bung cooked the snail.'
adverbial:
preposition:
WH-question:
'Bung cooked too much.'
'Bung cooked with soup.'
'What did Bung eat?'
b. LTS doesn't apply
Multiverb: $\quad$ Bún tò lám ̀̀ mè
Y-N question: Bún tà lám à
Final position: Bún á tô lám

\author{
'Bung finished cooking/cooked completely.' \\ 'Did Bung cook?' \\ 'Bung cooked.'
}

As seen in (4a), it is only a L-H noun which becomes M-H. In other cases the H of the verb /lám/ is lost although /gh̀̀/ 'what' has acquired the H (cf. Búy tà kùm gh̀̀ 'what did Bung touch?'). In (4b) LTS does not apply when followed either by a consecutivized verb ('cook \& finish') or the yes-no question marker /à/. The last example shows that LTS also will not apply if the monosyllabic verb is final. Since the conjoint verb form cannot occur finally in a main clause affirmative (MCA), the corresponding disjoint form is cited (where the L tone P2 marker/tò/ becomes HL [tô] by H tone spreading from the preceding DJ marker /á/ see discussion in §3). Finally, it should be noted that a bisyllabic $\mathrm{H}-\mathrm{H}$ verb undergoes LTS independent of what follows, hence finally: Búy á tô sàntà 'Bung sifted'.

In the following discussion we will almost exclusively cite forms where the verb is followed by the object noun kàbáyn 'fufu' (a staple food) so that we can see whether the process of LTS occurs. In the following sections we first analyze the indicative tense-aspect contrasts starting with perfective ( $\$ 3)$, then progressive ( $\S 4)$, and negative ( $\S 5)$, and then turn to non-indicative forms in $(\S 6, \S 7)$. We end in $\S 8$ by outlining an analysis which ranks the TAM inflectional features seen to determine the different tonal patterns in the earlier sections.

\section{Perfective forms}

In this section we will introduce the temporal contrasts and describe their realization in the perfective aspect. As summarized in Table 3, Babanki distinguishes four present/past and three future tenses, which we refer to as $\mathrm{P} 0-\mathrm{P} 3$ and $\mathrm{F} 1-\mathrm{F} 3$. We indicate the pre-verbal segmental tense auxiliaries which are held constant across the perfective and progressive aspects as well as in the corresponding negatives. (F2 nè and F3 lì are also consistently present in non-indicative moods.)

Table 3: Babanki tense distinctions

\begin{tabular}{c|c|l} 
Tense & AUX & \multicolumn{1}{l}{ Approximate time period } \\
\hline P0 & ỳ̀ & present, a few minutes ago \\
P1 & yì & today \\
P2 & tà & yesterday to about 2 weeks ago \\
P3 & ̀̀ N- & more than 2 weeks ago \\
F1 & à & not longer than in a few minutes \\
F2 & nè & later today \\
F3 & lù & from tomorrow on
\end{tabular}

As indicated, the P1, P2, F1, F2, and F3 tenses have L tone segmental auxiliaries. P0 does not have a segmental auxiliary and $\mathrm{P} 3$ requires a nasal prefix on the verb. Since tone is also involved, these markers 
tell only part of the story. In addition, in the perfective aspect there is a distinction between conjoint (CJ) and disjoint (DJ) forms in all seven tenses. We schematize the analysis of MCA perfective tense marking in Table 4, where ... refers to the position of the verb stem. The tonal marking is intended to be underlying, e.g. P1 DJ /á yì/ and P2 DJ /á tà/ which are however realized [á yî́] and [á tô] by H tone spreading. Examples involving all of the verbs in Table 2 can be found in Appendix 1.

\begin{tabular}{|c|c|c|}
\hline Tense & Conjoint & Disjoint \\
\hline P0 & $` \ldots$ & á ... ` lí \\
\hline $\mathrm{P} 1$ & yì ... & ว́ yì ... \\
\hline $\mathrm{P} 2$ & tว̀ ... & á tà ... \\
\hline P3 & ̀े $\mathrm{N} \ldots\left(^{\prime}\right)$ & á N ... 'lí \\
\hline $\mathrm{F} 1$ & à ... & ó à ...' \\
\hline $\mathrm{F} 2$ & nè ... & á nè ...' \\
\hline F3 & lù ... & ó lù ...' \\
\hline
\end{tabular}

Since the CJ/DJ distinction is found only in MCA perfective forms, we can refer to these directly as "conjoint" and "disjoint" or CJ and DJ. The above contrasts have all of the properties of the CJ/DJ contrast reported in Bantu, e.g. in the studies in van der Wal \& Hyman (2017): ${ }^{4}$

(i) The DJ is used with truth value focus, either contrastively ('Bung DID eat the fufu') or when the truth value is part of the assertion (i.e. not presupposed): 'Hey, guess what? Bung ate the fufu').

(ii) The CJ is used when the truth value is presupposed, either in answer to a question 'What happened?' (answer: 'Bung ate the fufu') or when focus is on another element of the utterance. This can be in answer to a WH question: 'Who ate the fufu?', answer: 'BUNG ate the fufu'; 'What did Bung eat?', answer: 'Bung ate the FUFU'; 'What did Bung do with the fufu?', answer: 'Bung ATE the fufu'. It can also be contrastive: 'Bung ate the FUFU, not the vegetables'.

(iii) The verb can occur at the end of a MCA sentence with DJ marking; it cannot occur at the end of a MCA sentence with CJ marking (there must be something following the verb).

(iv) There is no $\mathrm{CJ} / \mathrm{DJ}$ contrast in negatives or relative clauses (where the verb can occur last).

(v) As we will see in subsequent sections, non-contrastive negative and relative clause marking of $\mathrm{P}$ (non-future) tenses looks like the $\mathrm{CJ}$ marking in main clause affirmatives (where one does not expect focus marking of truth value). While this is typical of $\mathrm{CJ} / \mathrm{DJ}$ languages, the future tenses are different: their marking in negatives and relative clauses looks more like the DJ in main clause affirmatives.

(vi) The DJ forms are more segmentally marked than the CJ forms. As seen in Table 4, the DJ forms all involve a $\mathrm{H}$ tone schwa that precedes the TAM auxiliary. $\mathrm{P} 0$ and $\mathrm{P} 3$ also have a postposed marker /’lí/.

With this established, we now turn to consider the tonal patterns associated with each cell in the complex TAM system of Babanki. For this purpose we have prepared appendices of full sentences which are colorcoded for tone pattern. Although we will cite a subset of these forms in the text, readers will be referred to

\footnotetext{
${ }^{4}$ Although they differ in form, the Babanki CD/DJ also parallels the contrast reported in non-future tenses in Aghem, a Western Ring Grassfields Bantu language (Anderson 1979; Watters 1979), as well as in certain other non-Bantu languages (Hyman \& Watters 1984). More closely related within Central Ring, Kom also has a CJ/DJ contrast, again marked by different forms, as in the general past Ngóy tîjùm mēnywín (CJ) vs. Ngóy tí mēn jùm mènywīn (DJ) 'Ngong drove away the birds' (second author, personal notes).
} 
the relevant appendix for more examples. For ease of reference, we present an overview of indicative TA marking with color coding of the tone patterns in Table 5.

Table 5: Summary of indicative TA marking color-coded by tone pattern on the verb

\begin{tabular}{|c|c|c|c|c|c|}
\hline & \multicolumn{3}{|c|}{ indicative aff. } & \multicolumn{2}{|c|}{ indicative neg. } \\
\hline & CJ & DJ & ProG & PERF & PROG \\
\hline P0 & & á & & á kó & á kó’ \\
\hline P1 & yì & ว́ yî & yǐ & á kó yì & á kó yǐ \\
\hline $\mathrm{P} 2$ & tò & á tô & tə̌ & á kó tò & á kó tă \\
\hline P3 & ̀े & á & $\grave{\partial}$ & á kó & ว́ kó \\
\hline F1 & à & $\mathrm{á}^{\prime}$ & á & á kó & ว́ kó \\
\hline F2 & nè & á né & á né & á kó $\downarrow^{\downarrow}$ né & á kó ‘né \\
\hline F3 & lù & ว́ lú & á lú & ว́ kó لlú & ว́ kó لlú \\
\hline
\end{tabular}

Since we will consider each TA separately we will identify the tone patterns as we go. In $\S 8$, a fuller paradigm with all TAM forms is provided in Table 6 and the tone patterns identified in Table 7. For now, note that five different tone patterns have been identified, with progressive aspect (PROG) always assigning the same tone pattern to the verb, colored in green.

\subsection{Conjoint forms}

We start with the CJ forms, since they are segmentally and tonally simpler. Representative forms of all seven CJ tenses are provided in the first data column in Appendix 1, color-coded for tone pattern. Except for the $\mathrm{P} 3$, all of the cells are gray, indicating that the verb is preceded by a $\mathrm{L}$ auxiliary indicated above in Table 4. (The P0 auxiliary is a floating $\mathrm{L}$ tone.) While the $\mathrm{L}$ tone auxiliary has no effect on $\mathrm{L}$ tone roots, it causes $\mathrm{H}$ tone roots to become L by LTS, as in the P2 forms in (5).
a. Búy tà zhì
kə̄-báyn
'Bung ate the fufu.'
Bung P2 eat
7-fufu
b. Bún tò làm kə̄-báyn
Bung P2 cook 7-fufu
c. Bún tò sòntó kò-báyn
Bung P2 sift 7-fufu
'Bung cooked the fufu.'
'Bung sifted the fufu.'

The L of P2 /t̀̀/ spreads and delinks the underlying root $\mathrm{H}$ of /zh'́/ 'eat', /lám/ 'cook', and /sántə/ 'sift'. 5 In $(5 \mathrm{a}, \mathrm{b})$, where the verb stems are monosyllabic, this frees the $\mathrm{H}$, which then joins the $\mathrm{L}$ of the following class 7 noun prefix /k̀̀-/ to form a HL falling tone, subsequently simplified to $\mathrm{M}$ ( $k \hat{\partial}-\rightarrow k \bar{z}-)$. In the case of bisyllabic /sántə/ in (5c), the $\mathrm{H}$ delinks on the first syllable, with the suffix -tá maintaining the (spread) $\mathrm{H}$ tone, i.e. /sántə/ $\rightarrow$ sáytá $\rightarrow$ sàytá). Since the $\mathrm{H}$ of bisyllabic verbs is not reassigned to the following noun, the /kò-/ noun prefix remains $\mathrm{L}$, as it also is after a $\mathrm{L}$ tone verb.
a. Bún tò lè kò-báyn
Bung P2 lose 7-fufu
b. Bún tò kùm kà-báyn
Bung P2 touch 7-fufu
c. Búy tà lìmsà kà-báyn
Bung P2 heat 7-fufu

\footnotetext{
${ }^{5}$ Recall that suffixes are toneless, taking their tone from the root. As we will see, some TAMs assign a L suffixal tone that may cause a bisyllabic H root stem to be realized H-L (as in progressive forms - see §4), while other TAMs assign a $\mathrm{H}$ suffix tone that may cause a bisyllabic $\mathrm{L}$ root stem to be realized L-H (as in the P3 CJ as well as the imperatives seen in Table 2.)
} 
A glance at the other CJ tenses in Appendix 1 will reveal that with the exception of $\mathrm{P} 3$ they all share the same tone pattern. $\mathrm{P} 3$ is also exceptional in being the only perfective tense that requires a nasal prefix on the verb (also in the DJ). The H tone verbs undergo LTS and have the same realization as the other CJ tenses:
a. Bún ̀̀
n-zhì
kə̄-báyn
'Bung ate the fufu.'
b. Bún ̀̀ n-làm kə̄-báyn
'Bung cooked the fufu.'
Bung IPFV.P3 N-cook 7-fufu
c. Bún ̀̀ n-sə̀ytá kò-báyn
'Bung sifted the fufu.'

The L tone verbs, however, show a different pattern in P3:
a. Búy ̀̀ n-lèé kə̄-báyn
Bung IPFV.P3 N-lose 7-fufu
b. Bún ̀̀ y-kùmá kə̄-báyn
Bung IPFV.P3 N-touch 7-fufu
$\begin{array}{llll}\text { c. Bún ̀̀ } & \text { n-lìmsá kə̄-báyn } \\ \text { Bung IPFV.P3 } & \text { N-heat 7-fufu }\end{array}$
'Bung lost the fufu.'
'Bung touched the fufu.'
'Bung heated the fufu.'

First, the monosyllabic verbs acquire a second $\mathrm{H}$ tone schwa syllable seen most clearly after the CVC root in (8b), while the schwa assimilates to the vowel of a CV root, as in (8a). The H tone -á also conditions the class 7 prefix / k̀̀-/ to become M. Given that the L verbs show this different pattern, we have encoded the P3 CJ cell blue.

\subsection{Disjoint forms}

We are now ready to consider the corresponding DJ forms in the second data column of Appendix 1 . These all involve a DJ marker /á/ occurring between the subject and the verb (which however fuses with the /á/ auxiliary in the F1). Except for the spreading of the $\mathrm{H}$ of this /à/ onto the TAM auxiliaries /yì/ and /t̀े/, yielding [yî] and [tô], the P1 and P2 tone patterns are the same as CJ, hence shaded grey in Appendix 1. Again we illustrate with the P2 H and L verb forms in (9) and (10), respectively.
a. Búy á tô zhì kā-báyn
Bung PFV P2 eat 7-fufu
b. Búy ó tô làm kə̄-báyn
Bung PFV P2 cook 7-fufu
c. Búy á tô sàntá kà-báyn
Bung PFV P2 sift 7-fufu
(10)
a. Búy á tô là kà-báyn
Bung PFV P2 lose 7-fufu
b. Búy á tô kùm kà-báyn
Bung PFV P2 touch 7-fufu
$\begin{array}{lllll}\text { c. Búy à } & \text { tô lìmsà kà-báyn } \\ \text { Bung } & \text { PFV } & \text { P2 heat 7-fufu }\end{array}$
'Bung ate the fufu.'
'Bung cooked the fufu.'
'Bung sifted the fufu.'
'Bung lost the fufu.'
'Bung touched the fufu.'
'Bung heated the fufu.'

Both P0 and P3 work differently from the CJ and are shaded orange. First, they both acquire a post-verbal auxiliary / 'lí/, represented by the P3 DJ forms in (11) and (12).
$\begin{array}{lll}\text { a. } \quad \text { Búy } & \text { á } & \text { n-zhí } \\ \text { Bung } & \text { PFV.P3 } & \text { N-eat }\end{array}$
`lí kò-báyn
P3 7-fufu
'Bung ate the fufu.' 


\begin{tabular}{|c|c|c|c|c|c|}
\hline Bún & á & n-lám & ${ }^{\downarrow}$ lí & kə̀-báyn & \multirow[t]{2}{*}{ 'Bung cooked the fufu.' } \\
\hline Bung & PFV.P3 & N-cook & P3 & 7-fufu & \\
\hline Búy & á & n-sántó & ${ }^{\downarrow}{ } 1 ́$ & kə̀-báyn & \multirow[t]{2}{*}{ 'Bung sifted the fufu.' } \\
\hline Bung & PFV.P3 & N-sift & P3 & 7-fufu & \\
\hline Búy & á & n-léè & lí & kə̀-báyn & \multirow[t]{2}{*}{ 'Bung ate the fufu.' } \\
\hline Bung & PFV.P3 & N-lose & P3 & 7-fufu & \\
\hline Búy & á & y-kúmò & lí & kə̀-báyn & \multirow[t]{2}{*}{ 'Bung touched the fufu. } \\
\hline Bung & PFV.P3 & N-touch & P3 & 7-fufu & \\
\hline Búy & á & n-límsà & lí & kə̀-báyn & \multirow[t]{2}{*}{ 'Bung heated the fufu.' } \\
\hline Bung & PFV.P3 & N-heat & P3 & 7-fufu & \\
\hline
\end{tabular}

In (11) we see that the verbs are realized $\mathrm{H}$ followed by the downstep of $\downarrow l i$, which we interpret as triggered by a floating $\mathrm{L}$ tone. In (12) the $\mathrm{H}$ of the DJ auxiliary /á/ spreads through the toneless nasal prefix onto the verb, creating a HL sequence. In $(12 a, b)$ an extra mora is observed which avoids the creation of a HL falling tone on the roots: *[lê], *[kûm]. Since / lí/ is preceded by a L tone, there is no contrastive downstep, although Babanki is subject to automatic downstep or "downdrift". In the above forms and elsewhere where present, a nasal prefix is underlyingly toneless, realized $\mathrm{M}$ between $\mathrm{H}$ tones, otherwise $\mathrm{L}$ if preceded or followed by L. ${ }^{6}$ As seen in Appendix 1, the P0 DJ forms are identical to the P3 DJ except that they lack a nasal prefix.

This leaves the future DJ tenses, which have a still different tone pattern and hence are encoded yellow. As seen in Appendix 1, the $\mathrm{H}$ of the DJ marker /à/ spreads onto the future auxiliaries /à/, /nè/, and /lù/. Rather than creating a HL falling tone, the result is that the $\mathrm{L}$ of these markers is delinked. As seen in the F2 DJ forms in (13), the delinked L triggers downstep on $\mathrm{H}$ tone verbs. ${ }^{7}$
a. Bún á né 'zhí kā-báyn
Bung PFV F2 eat 7-fufu
b. Bún ó né لlám kō-báyn
Bung PFV F2 cook 7-fufu
$\begin{array}{lllll}\text { c. Bún á } & \text { né } & \downarrow \text { sóntó kō-báyn } \\ \text { Bung } & \text { PFV } & \text { F2 } & \text { sift } & 7 \text {-fufu }\end{array}$
'Bung will eat the fufu.'
'Bung will cook the fufu.'
'Bung will sift the fufu.'

The corresponding $\mathrm{L}$ tone verbs show that the future DJ forms also involve a post-verbal $\mathrm{H}$ which fuses with the L tone of the noun prefix /k̀̀-/, converting it to M:
a. Bún à né lè kə̄-báyn
Bung PFV F2 lose 7-fufu
b. Búy á né kùm kə̄-báyn
Bung PFV F2 touch 7-fufu
c. Búy à né lìmsá kə̄-báyn
Bung PFV F2 heat 7-fufu
'Bung will lose the fufu.'
'Bung will touch the fufu.'
'Bung will heat the fufu.'

Although only tonal, the presence of a second post-verbal DJ marker is of course less surprising given the post-verbal DJ marker / 'lí/ in the P0 and P3.

This completes our discussion of the CJ and DJ perfective forms. In the following section we examine the same tenses in the progressive aspect, provided in the third data column of Appendix 1.

\footnotetext{
${ }^{6}$ For discussion of the interaction of preconsonantal nasals with tone in the Babanki noun class system, see Akumbu \& Hyman (2017).

${ }^{7}$ Since /à/, /nè/, and /lù/ are auxiliaries, we might expect them to tolerate a HL tone, as in the P1 DJ [yî] and P2 DJ [tô]. We speculate that the reason the L delinks is that the F2 and F3 auxiliaries are less grammaticalized and hence retain some of their original lexical root status as earlier verbs (cf. nè 'do, act', lù 'rise up, get up in the morning'). They are, however, apparently not "lexical" enough to lengthen their vowel to *née and *lúù.
} 


\section{Progressive forms}

The first important thing to note is that the progressive forms do not distinguish CJ from DJ. There is only one form per tense which is marked by a nasal prefix except in the P0 and a/L/ schwa suffix on the verb. In most cases the L /-j/ suffix is realized with the same tone as the verb root:
a. Bún
lám-ó
kò-báyn
'Bung is cooking fufu.'
b. Bún tǒ
cook-PROG
7-fufu
Bung P2
n-lám-á
kò-báyn
'Bung was cooking fufu.'
N-cook-PROG 7-fufu
c. Bún á né
n-lám-á kò-báyn
N-cook-PROG 7-fufu
a. Bún
Bung
kùm-ว̀
touch-PROG
kə̀-báyn
'Bung is touching fufu.'
'Bung was touching fufu.'
7-fufu
b. Bún tǒ
y-kùm-̀̀ kə̀-báyn
Bung P2
N-touch-PROG 7-fufu
c. Bún á né Đ-kùm-à kà-báyn
Bung PFV F2 N-touch-PROG 7-fufu
'Bung was touching fufu.'

(16)

It is however the H-L pattern of the $\mathrm{CV}(\mathrm{C}) \mathrm{CV}$ verb stems /sə́ntə/ 'sift' and /shítə/ 'collect' that shows that the suffix must be L:

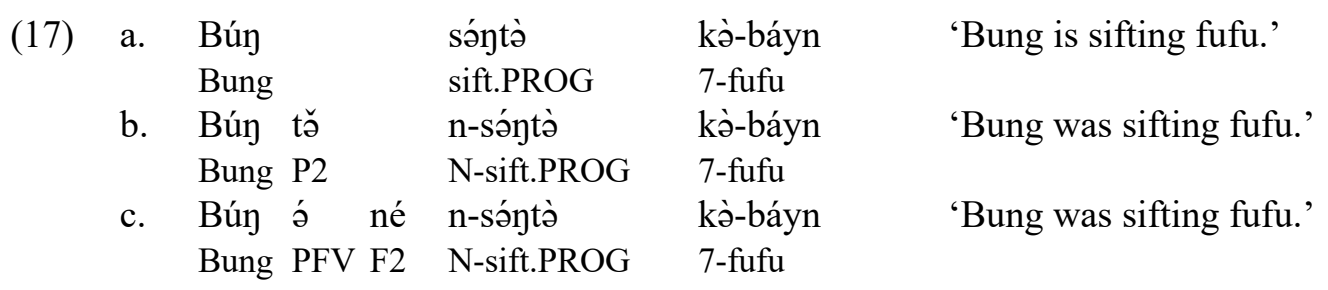

We therefore propose that the $\mathrm{H}$ of the root spreads and delinks the L of CV-̀े and CVC-ə̀ stems, producing an all $\mathrm{H}$ verb stem in (15), while $\mathrm{H}$ tone spreading is blocked when the verb stem has a suffix such as the /-tə/ in (17). In all cases the progressive L keeps the following /kò-/ suffix L. As seen in the above forms and in the third column of data in Appendix 1, what is significant is that all progressive forms have the same tonal pattern throughout all of the tenses, which overrides the distinctions found in other columns. ${ }^{8}$ We have shaded this pattern green.

To summarize thus far, while the input tense markers are the same as in Table 3, the following curious fact should be noted: the PST tenses show the same segmental marking as the CJ forms in column 1, while the FUT tenses have the same /á/ preceding the tense auxiliary as in the DJ forms in column 2. There are tonal differences, however. ${ }^{9}$ First, except in the P3, the PST tenses have a $\mathrm{H}$ tone following the tense

\footnotetext{
${ }^{8}$ As will be seen in $\S 5$ and $\S 6$, the same tone pattern is also found throughout the negative progressive paradigm as well as in non-indicative moods.

${ }^{9}$ The preverbal high tone effects in the future progressives seem to correlate with the postverbal high tones of the futures in the DJ paradigm. So on purely formal grounds one might come to think that actually the progressive future forms retain periphrastic traits in that the tense markers (two of which, F1 nè and F2 lù, have been identified as originating in erstwhile verbs) are inflected for the DJ (accounting for the tonal effects in the yellow cells of Appendix 1 ), whereas the verb itself is segmentally marked for the progressive by the marker combination $N-\ldots-j$. This leaves us with the (open) question of the semantic link between both categories, i.e. the progressive paradigm and the disjoint perfective paradigm in the future tenses. Taking this line of argumentation one step further and giving it a slightly different spin, one might as well see the quirky extra $\mathrm{H}$ tone in all progressive past tenses, except $\mathrm{P} 3$, in the same context, i.e. as taking part in a general progressive pattern of ' $N-\ldots$-̀े, possibly representing (relics of) an erstwhile periphrastic construction of an auxiliary plus nominalized main verb. Under this assumption, P0 and P3 stand out in
} 
auxiliary which produces a rising tone in the case of $\mathrm{P} 1$ and $\mathrm{P} 2: / \mathrm{yì̀}^{\prime} / \rightarrow$ [y̌̀ $], /$ tà'/ $\rightarrow$ [tă]. The same $\mathrm{H}$ tone accounts for the tonal differences between the P0 CJ and the corresponding progressive:
a. /Bún `ám kòbáyn/
$\rightarrow$ Bún làm kə̄báyn
'Bung has cooked the fufu.'
b. /Bún ' lám-à kàbáyn/
$\rightarrow$ Bún lámá kàbáyn
'Bung is cooking the fufu.'

As seen in (18a), a L tonal morpheme precedes the verb in the P0 CJ which links to the verb, causing its $\mathrm{H}$ to delink. The delinked $\mathrm{H}$ then causes the following /kò-/ noun prefix to become M. In contrast, in (18b) a $\mathrm{H}$ tonal morpheme precedes the verb in the P0 progressive, and the verb is realized $\mathrm{H}-\mathrm{H}$ with its schwa suffix. The /k̀̀-/ noun prefix is therefore not affected.

\section{Negative forms}

From the summary in Table 5 and the forms in Appendix 2 it can be observed that negative indicative verb forms all involve the markers á kó preceding the tense auxiliaries, as in the following P2 Neg perfective forms:
a. Búy á kó tò zhì kə̄-báyn Bung PFV NEG P2 eat 7-fufu
b. Bún á kó tò làm kə̄-báyn Bung PFV NEG P2 cook 7-fufu
c. Búy á kó tò sə̀ntó kə̄-báyn Bung PFV NEG P2 sift 7-fufu
'Bung did not eat the fufu.'
'Bung did not cook the fufu.'
'Bung did not sift the fufu.'
a. Bún á kó tà lè kò-báyn Bung PFV NEG P2 eat 7-fufu
b. Búy á kó tò kùm kə̀-báyn Bung PFV NEG P2 touch 7-fufu
c. Búy á kó tà lìmsà kà-báyn Bung PFV NEG P2 heat 7-fufu

As mentioned, there is no $\mathrm{CJ} / \mathrm{DJ}$ distinction in the negative, although it is tempting to identify the omnipresent negative $\mathrm{H}$ tone schwa as the same á observed in the DJ, summarized above in Table $4 .{ }^{10}$ Table 2 also shows that the progressives have the same tones as in the affirmative, again shaded in green. Thus compare the following sentences with those in (15) and (16).
a. Bún á kó ل لám-á kà-báyn 'Bung is not cooking fufu.' Bung PFV NEG cook-PROG 7-fufu
b. Bún á kó tă n-lám-á kà-báyn
Bung PFV NEG P2 N-cook-PROG 7-fufu
c. Bún ó kó ' 'né n-lám-á kò-báyn 'Bung will not be cooking fufu.'
Bung PFV NEG F2 N-cook-PROG 7-fufu

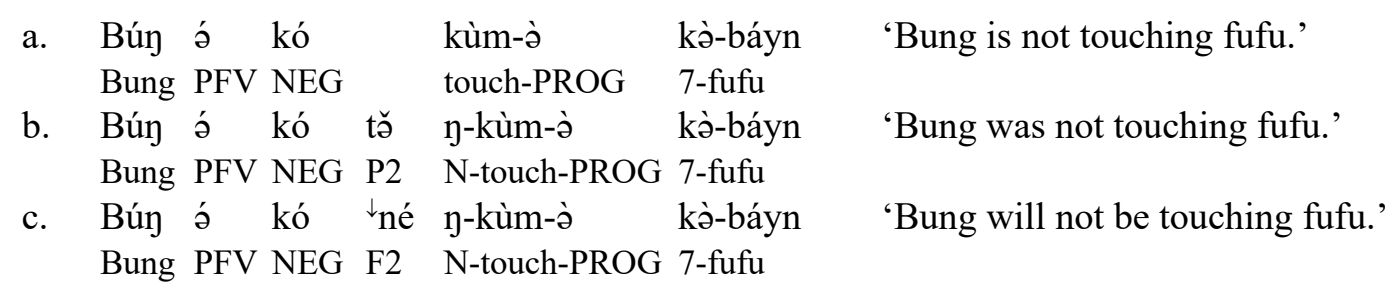

that they do not share the full package of markers, P0-PROG lacking N- and P3 lacking the preverbal H (and possibly also the progressive $\mathrm{N}$-, since the nasal prefix might as well be interpreted as the ordinary P3 marker).

${ }^{10}$ It is well known that both DJ and negation involve an inherent focus, hence form a natural class (see Hyman \& Watters 1984). 
The downsteps on $\downarrow^{\downarrow}$ lámá in (21a) and $\downarrow^{\downarrow} e ́$ in (21c) show that there is a floating L following kó. One might have proposed that the underlying representation of the negative indicative marker is /kò/ which would undergo $\mathrm{H}$ tone spreading from the preceding /á/, exactly as the F2 auxiliary /nè/ undergoes after the DJ marker /á/ in (13) and (14), and similarly in other future tenses in Appendix 1. However, since the nonindicative negative marker is /kó/, as in ká nzhüt kàbáyn 'don't be eating fufu!', it is equally likely that the negative indicative marker is /kó $\%$

Before concluding this section, we should note that there are some tonal differences between the perfective affirmative and negative paradigms. What is curious is that the $\mathrm{P}$ tenses take the same tones as the corresponding affirmative CJ forms (shaded in gray except for P3 blue), while the F tenses take the same tones as the corresponding affirmative DJ forms (shaded in yellow). We will return to this in $\S 8$, where we propose a ranked set of morphosyntactic tone assignment rules.

\section{Non-indicative affirmative forms}

In the preceding sections we have seen that Babanki distinguishes seven tenses in indicative forms: P0-P3 and F1-F3. In this and the following section we describe the non-indicative forms which by their semantics are all future-oriented. As a result each of them has only three forms which correspond to indicative F1F3. In addition, there is no CJ/DJ contrast. As we will see, only what we identify as F1 is really different from indicative marking in its tonal patterns.

We start with the singular imperative forms which were already shown in Table 2 above. As seen in Appendix 3, the bare F1 imperative has the same tone pattern as the indicative F1 DJ and negative, shaded yellow, while the F2 and F3 imperatives share the grey-shaded pattern of their corresponding CJ forms, as in $(23 \mathrm{~b}, \mathrm{c})$ involving the $\mathrm{H}$ tone verb /lám/ 'cook' and the L tone verbs /kùm/ 'touch' and /lìmsว̀/ 'heat': ${ }^{\prime}$

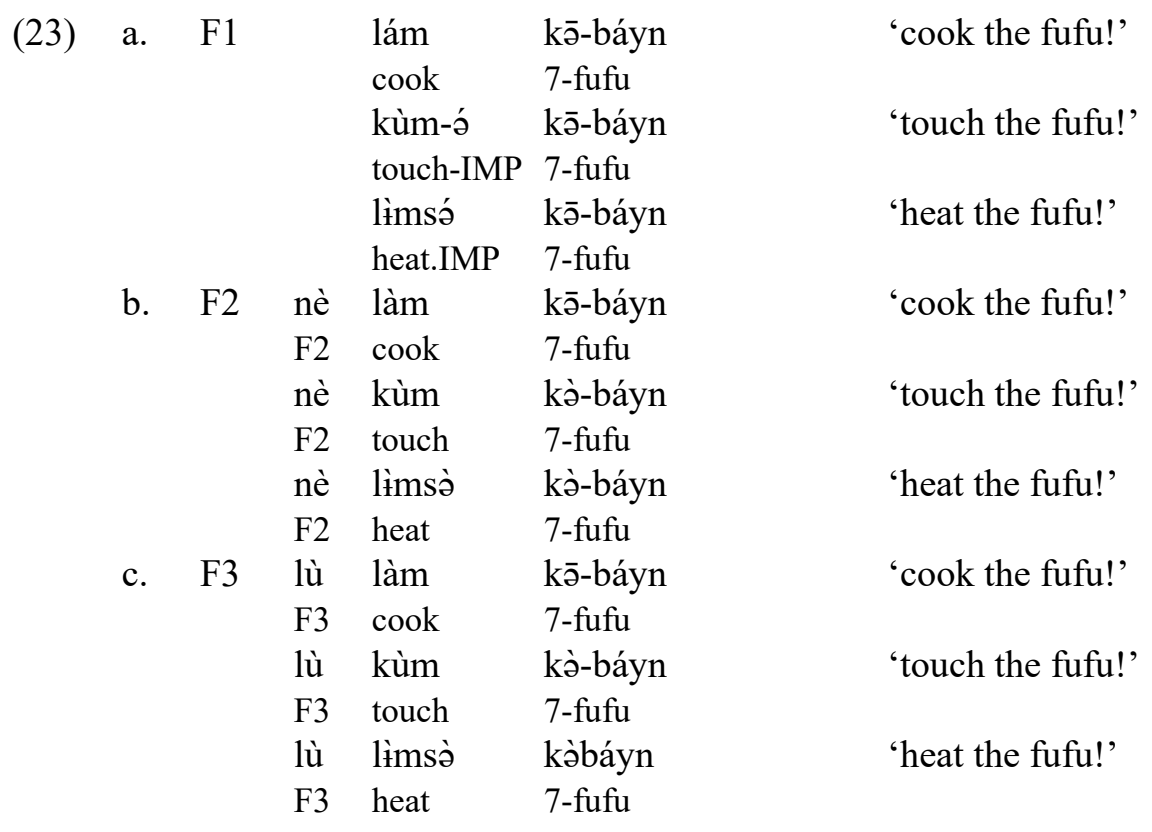

As in the future indicative forms, L tone verbs acquire a $\mathrm{H}$ tone schwa, hence kùmá 'touch!' in (23a). As seen in (24a), neither the F1 marker /à/ nor the H tone schwa suffix appear in the plural imperative.

\footnotetext{
${ }^{11}$ Full paradigms of the non-indicative forms discussed in this section can be found in Appendices 3-7.
} 


\begin{tabular}{|c|c|c|c|c|c|c|}
\hline \multirow[t]{5}{*}{ a. } & \multirow[t]{6}{*}{ F1 } & \multicolumn{2}{|l|}{ ghว̀y } & lám & kə̄-báyn & \multirow[t]{2}{*}{ 'you pl. cook the fufu!' } \\
\hline & & \multirow{2}{*}{\multicolumn{2}{|c|}{$\begin{array}{l}\text { 2PL } \\
\text { ghə̀y }\end{array}$}} & cook & 7-fufu & \\
\hline & & & & kúm & kò-báyn & 'you pl. touch the fufu!' \\
\hline & & \multirow{2}{*}{\multicolumn{2}{|c|}{$\begin{array}{l}\text { 2PL } \\
\text { ghว̀n }\end{array}$}} & touch & 7-fufu & \\
\hline & & & & límsó & kə̄-báyn & 'you pl. heat the fufu!' \\
\hline & & \multicolumn{2}{|l|}{$2 \mathrm{PL}$} & heat & 7-fufu & \\
\hline \multirow[t]{6}{*}{ b. } & \multirow[t]{6}{*}{$\mathrm{F} 2$} & ghòy & nè & làm & kə̄-báyn & 'you pl. cook the fufu!' \\
\hline & & $2 \mathrm{PL}$ & $\mathrm{F} 2$ & cook & 7-fufu & \\
\hline & & ghòy & nè & kùm & kə̀-báyn & 'you pl. touch the fufu!' \\
\hline & & $2 \mathrm{PL}$ & $\mathrm{F} 2$ & touch & 7-fufu & \\
\hline & & ghว̀y & nè & lìmsà & kò-báyn & 'you pl. heat the fufu!' \\
\hline & & $2 \mathrm{PL}$ & $\mathrm{F} 2$ & heat & 7-fufu & \\
\hline \multirow[t]{6}{*}{ c. } & \multirow[t]{6}{*}{ F3 } & ghว̀y & lù & làm & kə̄-báyn & 'you pl. cook the fufu!' \\
\hline & & $2 \mathrm{PL}$ & F3 & cook & 7-fufu & \\
\hline & & ghə̀y & lù & kùm & kə̀-báyn & 'you pl. touch the fufu!' \\
\hline & & $2 \mathrm{PL}$ & F3 & touch & 7-fufu & \\
\hline & & ghว̀y & lù & lìmsà & kà-báyn & 'you pl. heat the fufu!' \\
\hline & & 2PL & F3 & heat & 7-fufu & \\
\hline
\end{tabular}

However, the F1 plural imperative shows a $\mathrm{H}$ tone prefix, which links to a following L verb. As seen most clearly when the L verb is bisyllabic, a $\mathrm{H}^{-}{ }^{\downarrow} \mathrm{H}$ downstep sequence is created: /ghòn ' lìmsá kə̀báyn/ $\rightarrow$ ghà $\eta$ l'́m $\downarrow^{\downarrow}$ sá kàbáyn 'you pl. heat the fufu!'. ${ }^{12}$ In the case of a monosyllabic verb a $\mathrm{H}^{\downarrow} \mathrm{H}$ contour is expected on the one syllable. Instead, since such contours are not permitted, the second $\mathrm{H}$ is deleted, with the preceding L, now delinked, preserving the L on the prefix of 'fufu' ${ }^{13}$ Finally, note that the F2 and F3 forms in $(24 b, c)$ are identical to the F2-F3 indicative forms in Appendix 1. The same is true of the corresponding hortative forms in (25), extracted from Appendix 5.

\begin{tabular}{|c|c|c|c|c|c|c|}
\hline \multirow[t]{5}{*}{ a. } & \multirow[t]{6}{*}{$\mathrm{F} 1$} & \multicolumn{2}{|l|}{ yúwù } & lám & kə̄-báyn & \multirow[t]{2}{*}{ 'let's cook the fufu!' } \\
\hline & & 1PL & & cook & 7-fufu & \\
\hline & & yúwù & & kúm & kə̀-báyn & \multirow[t]{2}{*}{ 'let's touch the fufu!' } \\
\hline & & $1 \mathrm{PL}$ & & touch & 7-fufu & \\
\hline & & yúwù & & l'́m ${ }^{\downarrow}$ só & kə̀báyn & \multirow[t]{2}{*}{ 'let's heat the fufu!' } \\
\hline & & $1 \mathrm{PL}$ & & heat & 7-fufu & \\
\hline \multirow[t]{6}{*}{ b. } & \multirow[t]{6}{*}{$\mathrm{F} 2$} & yúwù & nè & làm & kə̄-báyn & \multirow{2}{*}{ 'let's cook the fufu!' } \\
\hline & & $1 \mathrm{PL}$ & F2 & cook & 7-fufu & \\
\hline & & yúwù & nè & kùm & kə̀-báyn & \multirow[t]{2}{*}{ 'let's touch the fufu!' } \\
\hline & & 1PL & F2 & touch & 7-fufu & \\
\hline & & yúwù & nè & lìmsà & kə̀-báyn & \multirow[t]{2}{*}{ 'let's heat the fufu!' } \\
\hline & & 1PL & $\mathrm{F} 2$ & heat & 7-fufu & \\
\hline \multirow[t]{6}{*}{ c. } & \multirow[t]{6}{*}{ F3 } & yúwù & lù & làm & kə̄-báyn & \multirow[t]{2}{*}{ 'let's cook the fufu!' } \\
\hline & & $1 \mathrm{PL}$ & F3 & cook & 7-fufu & \\
\hline & & yúwù & lù & kùm & kə̀-báyn & \multirow[t]{2}{*}{ 'let's touch the fufu!' } \\
\hline & & $1 \mathrm{PL}$ & F3 & touch & 7-fufu & \\
\hline & & yúwù & lù & lìmsò & kə̀-báyn & \multirow[t]{2}{*}{ 'let's heat the fufu!' } \\
\hline & & $1 \mathrm{PL}$ & F3 & heat & 7-fufu & \\
\hline
\end{tabular}

\footnotetext{
${ }^{12}$ We color this pattern gold in the appendices.

${ }^{13}$ We find this analysis preferable to restricting the suffixal $\mathrm{H}$ to all forms except monosyllabic $\mathrm{L}$ verbs. Recall that the suffixal $\mathrm{H}$ is needed after $\mathrm{H}$ verbs as well in order for the noun prefix to be raised to $\mathrm{M}$.
} 
Again the F1 has both a preceding H prefix and suffix, while the F2 and F3 forms are identical to those in the indicative in Appendix 1. (See Appendix 4 for more plural imperative examples.)

The same pattern is also found in the subjunctive forms in (26) and the future conditional forms in (27), extracted from Appendices 6 and $7:^{14}$
a. F1 ... lá yúwù
lám kə̄-báyn
'(Bung wants) that we cook the fufu.'
COMP 1PL
cook 7-cook
... lá yúwù
lám kə̀-báyn
COMP 1PL
kúm 7-cook
... lá yúwù
límsó kò-báyn
COMP 1PL
heat 7-cook
b. F2 ... lá yúwù nè làm kā-báyn
COMP 1pl F2 cook 7-fufu
... lá yúwù nè kùm kò-báy
COMP 1pl F2 touch 7-fufu
... lá yúwù nè lìmsò kò-báyn '(Bung wants) that we heat the fufu.'
COMP $1 \mathrm{pl} \quad \mathrm{F} 2$ heat 7-fufu
c. F3 ... lá yúwù lù làm kō-báyn '(Bung wants) that we cook the fufu.'
COMP 1pl F3 cook 7-fufu
... lá yúwù lù kùm kà-báyn '(Bung wants) that we touch the fufu.'
COMP 1pl F3 touch 7-fufu
... lá yúwù lù lìmsà kò-báyn '(Bung wants) that we heat the fufu.'
F3 heat 7-fufu
'(Bung wants) that we touch the fufu.'
'(Bung wants) that we heat the fufu.'
'(Bung wants) that we cook the fufu.'
'(Bung wants) that we touch the fufu.'

(27)
a. F1 sótsèn Búy
COND Bung
sátsèn Bún
COND Bung
sátsèn Búy
COND Bung
$\begin{array}{ll}\text { lám } & \text { kə̄-báyn } \\ \text { cook } & 7 \text {-fufu }\end{array}$
'if Bung cooks the fufu ...'
kúm kə̀-báyn
'if Bung touches the fufu ...'
touch 7-fufu
límsó kə̄-báyn
'if Bung heats the fufu ...'
b. F2 sótsc̀n Bún nè
COND
heats 7-fufu
COND Bung F2 cook 7-fufu
sátsèn Búy nè kùm kò-báyn
COND Bung F2 touch 7-fufu
sátsc̀n Bún nè lìmsò kò-báyn
'if Bung cooks the fufu ...'
COND Bung F2 heat 7-fufu
$\begin{array}{llllll}\text { c. F3 sátsc̀n } & \text { Bún lù } & \text { làm } & \text { kō-báyn } \\ \text { COND } & \text { Bung } & \text { F3 } & \text { cook } & 7 \text {-fufu }\end{array}$
sótsèn Bún lù kùm kò-báyn 'if Bung touches the fufu ...'
COND Bung F3 touch 7-fufu
sátsèn Búy lù lìmsà kò-báyn 'if Bung heats the fufu ...'
COND Bung F3 heat 7-fufu
'if Bung touches the fufu ...'
'if Bung heats the fufu ...'
'if Bung cooks the fufu ...'

Since the F2 and F3 forms are non-distinct from the corresponding indicative F2 and F3, it is reasonable to consider only F1 as a non-indicative. However, even the F1 non-indicative succumbs to the expected, greenshaded pattern that characterizes the progressive aspect throughout the verb paradigm:

\footnotetext{
${ }^{14}$ Since the past conditional forms take the same (yellow) tone pattern in both the affirmative and negative, they are treated together in the next section.
} 
(28)
a. IMP.SG á nlámó kə̀báyn
b. IMP.PL ghว̀y á nlámó kə̀báyn
c. HORT yúwù á nlámá kàbáyn
'be cooking the fufu!'
'you pl. be cooking the fufu!'
d. SBJV
...lá yúwù á nlámó kòbáyn
'let's be cooking the fufu!'
e. COND
sátsèn Búy dí? ká nlámá kàbáyn ...
'(Bung wants) that we be cooking the fufu.'
'if Bung is cooking the fufu...'

In the following section we will see that, with the exception of the conditional negative, the corresponding negative forms largely tell the same story.

\section{$7 \quad$ Non-indicative negative forms}

As seen first in the following singular imperative forms taken from Appendix 9, the negative markers are consistently different in indicative vs. non-indicative forms.
a. F1 ká
${ }^{\downarrow}$ lám kə̄-báyn
'don't cook the fufu!'
NEG.F1
cook 7-fufu
ká kùm kō-báyn
'don't touch the fufu!'
NEG.F1 touch 7-fufu
ká lìmsá kā-báyn
'don't heat the fufu!'
NEG.F1 heat 7-fufu
$\begin{array}{lllll}\text { b. F2 ká né } & { }^{\downarrow} \text { lám } & \text { kə̄báyn } \\ & \text { NEG } & \text { F2 } & \text { cook } & \text { 7-fufu }\end{array}$
'don't cook the fufu!'
kó né kùm kə̄-báyn
'don't touch the fufu!'
NEG F2 touch 7-fufu
ká né lìmsó kō-báyn
'don't heat the fufu!'
c. F3 kó lú ${ }^{\downarrow}$ lám $\quad$ kōbáy
'don't cook the fufu!'
NEG F3 cook 7-fufu
kó lú kùm kə̄-báyn
'don't touch the fufu!'
NEG F3 touch 7-fufu
kó lú lìmsá kə̄-báyn
'don't heat the fufu!'

Whereas we established /kó \% as the indicative negative marker, the forms in (29) show that the nonindicative marker is /kó/, which however fuses with the F1 marker /à/ in (29a). The H of / ká/ spreads onto the tense marker, delinking its L, which then triggers a downstep on a following H: /ká à/, /ká nè/, /ká lù/ $\rightarrow$ ká ', ká né ', ká lú `. Finally, although /kùm/ 'touch' lacks the final H tone schwa seen in the affirmative imperative, it is clear that all of the above forms have a $\mathrm{H}$ suffix, hence a M tone on the prefix $k \bar{\partial}-$.

The corresponding negative plural imperatives taken from Appendix 10 appear in (30).
a. F1 kó ghòn
NEG $2 \mathrm{PL}$
lám kə̄-báy $n$
'you pl. don't cook the fufu!'
kə́ ghòn
cook
7-fufu
NEG 2PL
kúm kò-báyn
'you pl. don't touch the fufu!'
ká gh̀̀y
touch 7-fufu
'you pl. don't heat the fufu!'
NEG 2PL
límsá kò-báyn
heat 7-fufu
b. F2 k’́ ghàn nè
làm kə̄-báyn
NEG 2PL F2
cook
7-fufu
kó ghòn nè kùm kò-báyn
NEG 2PL F2 touch 7-fufu
ká ghòy nè lìmsà kò-báyn
NEG 2PL F2 heat 7-fufu
'you pl. don't cook the fufu!'
'you pl. don't touch the fufu!'
'you pl. don't heat the fufu!' 


\begin{tabular}{|c|c|c|c|c|c|c|}
\hline \multirow[t]{6}{*}{ c. F3 } & ká & ghว̀y & lù & làm & kə̄-báyn & \multirow[t]{2}{*}{ 'you pl. don't cook the fufu!' } \\
\hline & NEG & $2 \mathrm{PL}$ & F3 & cook & 7-fufu & \\
\hline & ká & ghว̀y & lù & kùm & kə̀-báyn & \multirow[t]{2}{*}{ 'you pl. don't touch the fufu!' } \\
\hline & NEG & $2 \mathrm{PL}$ & F3 & touch & 7-fufu & \\
\hline & k’́ & ghว̀y & lù & lìmsว̀ & kə̀-báyn & \multirow[t]{2}{*}{ 'you pl. don't heat the fufu!' } \\
\hline & NEG & $2 \mathrm{PL}$ & F3 & heat & 7-fufu & \\
\hline
\end{tabular}

This paradigm is exactly identical to that of the corresponding affirmatives in (24), except for the presence of ká occurring before the subject, here the second person plural pronoun gh̀̀ . The hortatives in (31) differ only in the presence of the first person plural pronoun yúwù, from Appendix 10, and similarly the subjunctives in (32) from Appendix 12 differ only in the presence of the complementizer lá:

\begin{tabular}{|c|c|c|c|c|c|c|}
\hline \multirow[t]{5}{*}{ a. } & ká & yúwù & & lám & kə̄-báyn & 'let's not cook the fufu!' \\
\hline & NEG & $1 \mathrm{pl}$ & & cook & 7-fufu & \\
\hline & ká & yúwù & & kúm & kə̀-báyn & 'let's not touch the fufu!' \\
\hline & NEG & $1 \mathrm{pl}$ & & touch & 7-fufu & \\
\hline & ká & yúwù & & l'́mı́ sá & kə̄-báyn & 'let's not heat the fufu!' \\
\hline & NEG & $1 \mathrm{pl}$ & & heat & 7-fufu & \\
\hline F2 & ká & yúwù & nè & làm & kə̄-báyn & 'let's not cook the fufu!' \\
\hline & NEG & & F2 & cook & 7-fufu & \\
\hline & k’́ & yúwù & nè & kùm & kə̀-báyn & 'let's not touch the fufu!' \\
\hline & NEG & $1 \mathrm{pl}$ & F2 & touch & 7-fufu & \\
\hline & ká & yúwù & nè & lìmsà & kə̀-báyn & 'let's not heat the fufu!' \\
\hline & NEG & $1 \mathrm{pl}$ & F2 & heat & 7-fufu & \\
\hline \multirow[t]{6}{*}{ c. } & ká & yúwù & lù & làm & kə̄-báyn & 'let's not cook the fufu!' \\
\hline & NEG & $1 \mathrm{pl}$ & $\mathrm{F} 3$ & cook & 7-fufu & \\
\hline & ká & yúwù & lù & kùm & kə̀-báyn & 'let's not touch the fufu!' \\
\hline & NEG & $1 \mathrm{pl}$ & F3 & touch & 7-fufu & \\
\hline & k’́ & yúwù & lù & lìmsə̀ & kə̀-báyn & 'let's not heat the fufu!' \\
\hline & NEG & $1 \mathrm{pl}$ & F3 & heat & 7-fufu & \\
\hline
\end{tabular}

\begin{tabular}{|c|c|c|c|c|c|c|c|c|}
\hline \multirow[t]{5}{*}{ a. } & \multirow[t]{5}{*}{$\mathrm{F} 1$} & ... lá & kə́ & yúwù & & lám & kə̄-báyn & '(Bung wants) that we not cook the fufu!' \\
\hline & & COMP & NEG & $1 \mathrm{pl}$ & & cook & 7-fufu & \\
\hline & & ... lá & kó & yúwù & & úm & kə̀-báyn & '(Bung wants) that we not touch the fufu!' \\
\hline & & COMP & NEG & $1 \mathrm{pl}$ & & uch & 7-fufu & \\
\hline & & ... lá & kó & yúwù & & lím $\downarrow^{\downarrow}$ ś & kə̀-báyn & '(Bung wants) that we not heat the fufu!' \\
\hline \multirow{7}{*}{ b. } & & COMP & NEG & $1 \mathrm{PL}$ & & & 7-fufu & \\
\hline & $\mathrm{F} 2$ & ... lá & ká & yúwù & nè & $\mathrm{m}$ & kə̄-báyn & '(Bung wants) that we not cook the fufu!' \\
\hline & & COMP & NEG & 1PL & F2 & ok & 7-fufu & \\
\hline & & ... lá & kə́ & yúwù & nè & kùm & kə̀-báyn & '(Bung wants) that we not touch the fufu!' \\
\hline & & COMP & NEG & $1 \mathrm{PL}$ & $\mathrm{F} 2$ & uch & 7-fuf & \\
\hline & & ... lá & kə́ & yúwù & nè & lìmsà & kə̀-báyn & '(Bung wants) that we not heat the fufu!' \\
\hline & & COMP & NEG & & $\mathrm{F} 2$ & & 7-fu & \\
\hline \multirow[t]{6}{*}{ 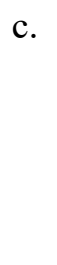 } & F3 & ... lá & ká & yúwù & lù & làm & kə̄-báyn & '(Bung wants) that we not cook the fufu!' \\
\hline & & COMP & NEG & $1 \mathrm{PL}$ & F3 & & 7-fu & \\
\hline & & ... lá & kə́ & yúwù & lù & kùm & kذ̀-báyn & '(Bung wants) that we not touch the fufu!' \\
\hline & & COMP & NEG & 1PL & F3 & ouch & 7-fufu & \\
\hline & & ... lá & kə́ & yúwù & lù & lìmsà & kə̀-báyn & '(Bung wants) that we not heat the fufu!' \\
\hline & & COMP & NEG & 1PL & F3 & heat & 7-fufu & \\
\hline
\end{tabular}


It is clear that the plural imperative, hortative, and subjunctive F1 realize the same non-indicative mood which we can call subjunctive, while the F2 and F3 inflections are indistinguishable from the corresponding indicative forms. Not so with the negative conditional, which requires a more complex realization, the following from Appendix 13:
a. F1 sátsèn Bún
dí? kó
COND Bung
COP NEG
lám kə̄-báyn
'if Bung doesn't cook the fufu ...'
sátsèn Búy
dí? ká
cook 7-fufu
COND Bung
COP NEG
kùm kə̄-báyn
'if Bung doesn't touch the fufu ...'
sótsèn Bún
dí? ká
touch 7-fufu
COND Bung
COP NEG
b. F2 sátsèn Búy nè dì? ká
lìmsá kə̄-báyn
'if Bung doesn't heat the fufu ...'
heat 7-fufu
COND Bung F2 COP NEG
lam kə̄-báyn
'if Bung doesn't cook the fufu ...'
sátsèn Bún nè dì? ká
COND Bung F2 COP NEG
cook 7-fufu
sátsc̀n Búy nè dì? kó lìmsá kə̄-báyn
COND Bung F2 COP NEG heat 7-fufu

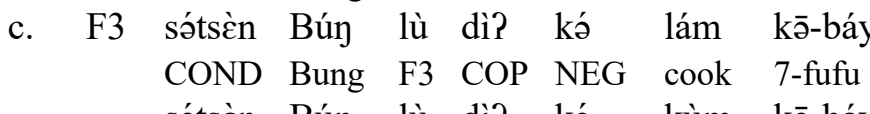
sátsèn Búy lù dì? ká kùm kā-báyn 'if Bung doesn't touch the fufu ...'
COND Bung F3 COP NEG touch 7-fufu
sátsèn Bún lù dì? kó lìmsá kō-báyn 'if Bung doesn't heat the fufu ...'
COND Bung F3 COP NEG heat 7-fufu

While the F1 doesn't have an overt tense marker, the F2 and F3 markers nè and lì appear before another morpheme $d i$ ? followed by the negative morpheme $k \dot{b}$. Since $d i$ ? is identical to the copular verb /dì/ 'be', we interpret the above historically as 'if Bung will be not cook, touch, heat...'. The main verb lacks a $\mathrm{H}$ prefix in the F1, although the F1-F3 all have a H suffix. We have thus colored these cells yellow in Appendix 13, indicating that the tones are identical with the indicative future pattern, which is in turn the same in the affirmative and negative (see Appendices 1 and 2).

Finally, as seen in Appendices 8 and 14, the affirmative and negative past conditional forms all take the same (yellow) tone pattern. The following representative examples show that instead of the pre-subject complementizer sátsèn, the auxiliary form $t i ́$ occurs after the tense marker in the past conditional:

\begin{tabular}{|c|c|c|c|c|c|c|c|}
\hline \multirow[t]{16}{*}{ (34) } & \multirow[t]{6}{*}{ a. } & \multirow[t]{6}{*}{ P0 } & Bún & tí & ${ }^{\downarrow}$ lám & kə̄báyn & \multirow[t]{2}{*}{ 'if Bung had cooked the fufu ...' } \\
\hline & & & Bung & COND & cook & 7-fufu & \\
\hline & & & Bún & tí & kùm & kə̄báyn & \multirow[t]{2}{*}{ 'if Bung had touched the fufu ...' } \\
\hline & & & Bung & COND & touch & 7-fufu & \\
\hline & & & Bún & tí & lìmsá & kə̄báyn & \multirow[t]{2}{*}{ 'if Bung had heated the fufu ...' } \\
\hline & & & Bung & COND & heat & 7-fufu & \\
\hline & \multirow[t]{6}{*}{ b. } & P1 & Bún yì & tí & ${ }^{\downarrow}$ lám & kə̄báyn & \multirow{2}{*}{ 'if Bung had cooked the fufu ...' } \\
\hline & & & Bung P1 & COND & cook & 7-fufu & \\
\hline & & & Bún yì & tí & kùm & kābáyn & \multirow[t]{2}{*}{ 'if Bung had touched the fufu ...' } \\
\hline & & & Bung P1 & COND & touch & 7-fufu & \\
\hline & & & Bún yì & tí & lìmsá & kābáyn & \multirow[t]{2}{*}{ 'if Bung had heated the fufu ...' } \\
\hline & & & Bung P1 & COND & heat & 7-fufu & \\
\hline & \multirow[t]{4}{*}{ c. } & $\mathrm{P} 2$ & Bún tò & tí & ${ }^{\downarrow}$ lám & kābáyn & \multirow[t]{2}{*}{ 'if Bung had cooked the fufu ...' } \\
\hline & & & Bung P2 & COND & cook & 7-fufu & \\
\hline & & & Bún tà & & kùm & kə̄báyn & 'if Bung had touched the fufu ...' \\
\hline & & & Bung P2 & COND & touch & 7-fufu & \\
\hline
\end{tabular}




\begin{tabular}{|c|c|c|c|c|c|}
\hline \multirow{8}{*}{ d. } & Bún tò & tí & lìmsá & kə̄báyn & \multirow[t]{2}{*}{ 'if Bung had heated the fufu ...' } \\
\hline & Bung P2 & COND & heat & 7-fufu & \\
\hline & Búy ̀̀ & n-tí & ${ }^{\downarrow}$ lám & kōbáyn & 'if Bung had cooked the fufu ...' \\
\hline & Bung P3 & N-COND & cook & 7-fufu & \\
\hline & Búy ̀̀ & n-tí & kùm & kə̄báyn & 'if Bung had touched the fufu ...' \\
\hline & Bung P3 & $\mathrm{N}-\mathrm{COND}$ & touch & 7-fufu & \\
\hline & Bún & n-tí & lìmsá & kə̄báyn & 'if Bung had heated the fufu ...' \\
\hline & Bung P3 & $\mathrm{N}-\mathrm{COND}$ & heat & 7-fufu & \\
\hline
\end{tabular}

Since $t i$ takes a nasal prefix in the P3, it is likely that $t i$ was once a verb, although its original meaning cannot be ascertained. ${ }^{15}$ The corresponding negatives are provided in (35).

\begin{tabular}{|c|c|c|c|c|c|c|c|c|}
\hline \multirow[t]{6}{*}{ a. } & \multirow[t]{6}{*}{$\mathrm{P} 0$} & Bún & tí & dì? & ká & ${ }^{\downarrow}$ lám & kābáyn & \multirow[t]{2}{*}{ 'if Bung hadn't cooked the fufu ...' } \\
\hline & & Bung & COND & COP & NEG & cook & 7-fufu & \\
\hline & & Bún & tí & dì? & ká & kùm & kə̄báyn & \multirow[t]{2}{*}{ 'if Bung hadn't touched the fufu ...' } \\
\hline & & Bung & COND & COP & NEG & touch & 7-fufu & \\
\hline & & Búy & tí & dì? & ká & lìmsá & kə̄báyn & \multirow[t]{2}{*}{ 'if Bung hadn't heated the fufu ...' } \\
\hline & & Bung & COND & COP & NEG & heat & 7-fufu & \\
\hline \multirow[t]{6}{*}{ b. } & \multirow[t]{6}{*}{ P1 } & Bún & yì tí & dì? & ká & ${ }^{\downarrow}$ lám & kə̄báyn & \multirow[t]{2}{*}{ 'if Bung hadn't cooked the fufu ...' } \\
\hline & & Bung & P1 COND & COP & NEG & cook & 7-fufu & \\
\hline & & Bún & yì tí & dì? & ká & kùm & kābáyn & \multirow[t]{2}{*}{ 'if Bung hadn't touched the fufu ...' } \\
\hline & & Bung & P1 COND & COP & NEG & touch & 7-fufu & \\
\hline & & Bún & yì tí & dì? & ká & lìmsá & kābáyn & \multirow[t]{2}{*}{ 'if Bung hadn't heated the fufu ...' } \\
\hline & & Bung & P1 COND & COP & NEG & heat & 7-fufu & \\
\hline \multirow[t]{6}{*}{ c. } & P2 & Bún & tò tí & dì? & ká & ${ }^{\downarrow}$ lám & kābáyn & \multirow[t]{2}{*}{ 'if Bung hadn't cooked the fufu ...' } \\
\hline & & Bung & P2 COND & COP & NEG & cook & 7-fufu & \\
\hline & & Bún & tò tí & dì? & ká & kùm & kābáyn & \multirow[t]{2}{*}{ 'if Bung hadn't touched the fufu ...' } \\
\hline & & Bung & P2 COND & COP & NEG & touch & 7-fufu & \\
\hline & & Bún & tò tí & dì? & ká & lìmsá & kābáyn & \multirow[t]{2}{*}{ 'if Bung hadn't heated the fufu ...' } \\
\hline & & Bung & P2 COND & $\mathrm{COP}$ & NEG & heat & 7-fufu & \\
\hline \multirow[t]{6}{*}{ d. } & P3 & Bún & ̀̀ n-tí & dì? & ká & ${ }^{\downarrow}$ lám & kə̄báyn & \multirow[t]{2}{*}{ 'if Bung hadn't cooked the fufu ...' } \\
\hline & & Bung & P3 N-COND & $\mathrm{COP}$ & NEG & cook & 7-fufu & \\
\hline & & Bún & ̀̀ n-tí & dì? & ká & kùm & kə̄báyn & \multirow[t]{2}{*}{ 'if Bung hadn't touched the fufu ...' } \\
\hline & & Bung & P3 N-COND & $\mathrm{COP}$ & NEG & touch & 7-fufu & \\
\hline & & Bún & ̀̀ n-tí & dì? & ká & lìmsá & kābáyn & \multirow[t]{2}{*}{ 'if Bung hadn't heated the fufu ...' } \\
\hline & & Bung & P3 N-COND & COP & NEG & heat & 7-fufu & \\
\hline
\end{tabular}

The same auxiliary + negative sequence $d i ? k a$ is used as in the future negative conditional.

This completes our survey through the different verb paradigms which we have been able to consider in our study. We conclude in $\S 8$ by outlining an integrative analysis followed by discussion.

\section{Towards an integrated analysis}

In the preceding sections we have presented the different Babanki tense, aspect, and mood distinctions, both affirmative and negative. While we have presented a subset of examples of each, a full and systematic presentation of all of the forms we have considered is found in Appendices 1-14. While we have given partial interpretations and analyses, we have yet to pull it all together into one coherent picture. This is our first goal in this section. Our second goal, however preliminary, will be to comment on what we think is the most promising conceptualization of the Babanki verb inflectional system and others like it.

\footnotetext{
${ }^{15}$ It is not clear if or how the past conditional auxiliary could derive from the present day Babanki verb $t i$ ' $m a k e$ a bed (from bamboo)' or the lexicalized causative verb tísá 'arrange'.
} 
We begin by recapping the preverbal "auxiliaries" in Table 6, where the different cells in the paradigm are also color-coded for tone pattern. ${ }^{16}$

Table 6: Preverbal segmental and tonal marking in the Babanki verb paradigm

\begin{tabular}{|c|c|c|c|c|c|c|c|c|c|c|c|c|c|c|}
\hline & & licativ & aff & ind & leg & $\mathrm{im}$ & aff & $\mathrm{imp}$ & neg & $\begin{array}{l}\text { imp. } \\
\text { hor } \\
\text { sbj } \\
\text { conc }\end{array}$ & $\begin{array}{l}\text { aff. } \\
\text { aff } \\
\text { aff } \\
\text { aff. }\end{array}$ & $\begin{array}{l}\text { imp. } \\
\text { hor } \\
\text { sbj }\end{array}$ & $\begin{array}{l}\text { l.neg } \\
\text { neg } \\
\text { neg }\end{array}$ & cond.neg \\
\hline & CJ & DJ & PR & PF & PR & PF & PR & PF & PR & PF & PR & PF & PR & PF, PR \\
\hline $\mathrm{P} 0$ & i & á & ' & á kó & á kó & & & & & tí & & & & tí dì? kó \\
\hline P1 & yì & á yî & y̌̃ & á kó yì & á kó yĭ & & & & & yì tí ${ }^{\circ}$ & & & & yì tí dì? ká \\
\hline P2 & tà & á tô & tă & á kó tà & á kó tǒ & & & & & tà tí ${ }^{\circ}$ & & & & tà tí dì? ká \\
\hline P3 & ̀̀ & á & ̀̀ & á kó & á kó & & & & & ̀̀ntí & & & & ว̀ ntí dì? kó \\
\hline $\mathrm{F} 1$ & à & $a^{\prime}$ & á & á kó & á kó & $\varnothing$ & ̀े & ká & ká & ' & á & ká...' & ká...ó & dí? kó \\
\hline $\mathrm{F} 2$ & nè & á né & á né & á kó ${ }^{\downarrow}$ né & á kó ${ }^{\downarrow}$ né & nè & né & ká né & ká né & nè & né & ká...nè & ká...né & nè dì? ká \\
\hline F3 & lù & á lú & ó lú & á kó \lú & á kó lú & lù & lú & ká lú ` & kó lú & lù & lú & ká...lù & ká...lú & lù dì? kó \\
\hline
\end{tabular}

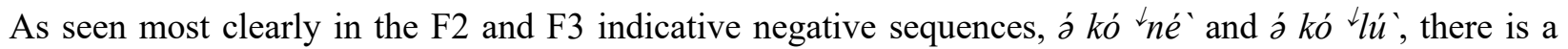
maximum of three segmental slots, which we can label as FOCUS, NEGATION, and TENSE. The only filler of the focus slot is the DJ marker/á/, which we assume is the same morpheme as the ['́] that precedes the indicative negative marker $/$ kó $\%$, but does not occur with the non-indicative negative marker $/ \mathrm{kó} /{ }^{17}$ This leaves the P0-P3 and F1-F3 tense markers which were presented in Table 1 above and are held constant throughout the paradigm. Except for the unassociated L tones, the intention in Table 6 is to show the output forms, including tonal variations that were discussed in earlier sections, e.g. P1 $y \grave{\imath}, y \hat{\imath}$, and $y \grave{l}$. We have proposed that the underlying forms of the tense markers are as they appear in the first (CJ) column, where they all have underlying $\mathrm{L}$ tone. Although the L tone does not appear in the P0 or P3 DJ (whose tone pattern is irregular), it is only the F1 that is inconsistent in its segmental marking: /à/ appears only in the indicative affirmative and the singular imperative negative, where $k a ́$ is the realization of $/ \mathrm{k} \dot{a} /+/ \mathrm{a} /$. Otherwise the variations in tense marking are largely tonal: While the P1 and P2 markers /yì/ and /t̀े/ become HL falling tone [yî] and [tô] after the DJ marker /à/, the future auxiliaries /nè/ and /lù/ instead become H tone [né] and [lú] plus a delinked L tone which, except in the progressive, causes a following $\mathrm{H}$ to become downstepped. In the progressive $\mathrm{H}$ and $\mathrm{L}$ tone verbs begin with their base tone, hence without any interaction with what precedes. This might be attributable to the fact that, except in the P0, progressives take a nasal prefix that may effectively block any tonal interaction with what precedes. ${ }^{18}$

The progressive is in fact quite special in the paradigm. As discussed in $\S 4$, progressive forms are consistent in their tone pattern: Except in the P0, the verb takes a toneless nasal prefix, and all progressives assign a $\mathrm{L}$ tone -̀े suffix, which however assimilates to the $\mathrm{H}$ of a monosyllabic $\mathrm{H}$ tone verb: /n-lám-ว̀/ 'cook.PROG' $\rightarrow$-lám-á. Outside the progressive, it is only the P3 that also takes a nasal prefix. Curiously, the $\mathrm{P} 3$ also assigns a schwa suffix, but only to L tone monosyllabic verbs, e.g. to /kùm/ 'touch' in Búy j̀

${ }^{16}$ In Table 6, PF stands for perfective and PR for progressive. The three dots (...) in the non-indicative columns indicate the position of the subject, which follows the negative marker ká but precedes the tense marker. Note also that the yellow non-indicative P0-P3 cells refer exclusively to conditional clauses, which receive the same auxiliary markers in the corresponding empty green progressive cells to their right.

${ }^{17}$ Note that /á/ is not restricted to main clause indicatives, as it can also occur in a relative clause, e.g. kàbáyn á Bún á kó ‘né ‘lám 'the fufu that Bung will not cook (F2)'.

18 There are potentially two problems with this idea. First, as we have said, the P0 doesn't take a nasal prefix, but is tonally identical to the other progressive forms. Second, although the tone patterns are irregular, P3 non-progressives also place a nasal prefix on the verb, but do allow a tonal interaction with the preceding auxiliary: L tone spreading occurs in the P3 CJ and negative, while H tone spreading occurs in the P3 DJ, e.g. à + nshitá $\rightarrow$ à nshitá 'collected', á + nshis̀̀ $\rightarrow$ á nshís̀̀ 'removed'. 
ykùmá kābáyn (CJ) and Búy á ykúmà lí kàbáyn (DJ), both meaning 'Bung touched the fufu'. The same pattern is found only in one other cell, the affirmative singular imperative, which again assigns the schwa suffix only to monosyllabic L tone verbs: kùmá 'touch!'.

Finally, there is the issue of assigning prefixal and suffixal tones. In accounting for the surface realizations it is necessary to control for whether the verb stem is mono- or bisyllabic. Recall that we have analyzed bisyllabic verbs as having an underlyingly toneless second syllable which will take the same tone as the tone of the root unless overriden by a suffixal tone. With this in mind, Table 7 characterizes the six color-coded stem-tone patterns in terms of their preceding and following tonal environments. ( $\mathrm{T}$ stands for the base $/ \mathrm{H} /$ or $/ \mathrm{L} /$ of the verb root.)

Table 7: Summary of Babanki stem-tone patterns in tonal context

\begin{tabular}{|c|c|c|c|c|}
\hline & pre-verb & verb tone & suffix & tone on noun prefix kə- \\
\hline Grey & $\mathrm{L}$ & $\mathrm{L}-\mathrm{T}$ & $\varnothing$ & $\mathrm{L}$ except $\mathrm{M}$ after $1 \sigma / \mathrm{H} /$ stem \\
\hline Orange & á & $\mathrm{H}-\mathrm{T}$ & -̀̀ only on $1 \sigma \mathrm{L}$ verbs & L throughout \\
\hline Yellow & (L) & $\mathrm{T}-\mathrm{H}$ & -ó after L verbs in aff.imp.sg. & M throughout \\
\hline Blue & $\mathrm{L}$ & L-H & -á after L verbs & M except after $/ \mathrm{H}-\varnothing /$ stem \\
\hline Gold & $\mathrm{H}$ & $\mathrm{H}-(\mathrm{T})-\mathrm{H}$ & $-\mathrm{H}$ except after $1 \sigma \mathrm{L}$ verbs & M except after $1 \sigma / L /$ stems \\
\hline Green & $\mathrm{H}$ except $\mathrm{P} 3$ & T-L & -̀̀ except -ó after $1 \sigma \mathrm{H}$ verbs & L throughout \\
\hline
\end{tabular}

Only the grey pattern lacks a suffix. The P0 and P3 orange DJ cells are unique in requiring a non-suffixal formative / 1 li / following the verb. What is striking is that four of the six rows show an agreement between the pre-verb tone and the first tone of the verb stem: grey and blue L vs. orange and gold $\mathrm{H}$. In the first group $\mathrm{L}$ tone spreading causes a $\mathrm{H}-\mathrm{H}$ verb to be realized as $\mathrm{L}-\mathrm{H}$, while in the second group $\mathrm{H}$ tone spreading causes a L-L verb to become H-L. The (L) of the yellow row indicates that a $\mathrm{L}$ is sometimes present, but does not interact with the verb stem other than to cause a $\mathrm{H}$ verb to become downstepped, e.g. ká $+\grave{a}+$ lám + kàbáyn $\rightarrow$ ká 'lám kàbáyn $\rightarrow$ ká \lám kābáyn 'don't cook the fufu!' Finally, concerning the last row, shaded green, we have already seen that there is no tonal interaction between the auxiliary and the verb stem in progressives.

Turning to suffixes, both the P3 (orange) and progressives (green) assign a L, while yellow, blue and gold assign a H. Except for the gold pattern a schwa suffix also appears, although with the restrictions that are indicated. The $\mathrm{H}$ tone schwa is only found after $\mathrm{L}$ verbs - and is only discernible when the verb is monosyllabic. This is because a schwa would merge with the second vowel of a CV(C)CV verb stem. In fact, among the 757 verbs in Akumbu (2008), 323 verb stems are bisyllabic. Of these all but 19 have the shape CV(C)Cə. Of these 19, all but five have the shape CV?V where the vowels are identical, and three are clearly compounds. This leaves the following two verbs: bágli 'be ripe', bóbó 'carry (child) on back', on which a surface schwa does not accompany the suffixal L in the progressive: Búy yı̌ mbóbò kàbáyn 'Bung was carrying the fufu' (P1). While this accounts for why the schwa is visible only on monosyllabic verbs, e.g. directly on CVC roots or as an assimilated extra mora on CV roots, it does not explain why only the progressive assigns a schwa to both $\mathrm{H}$ and $\mathrm{L}$ roots. A clear generalization is that monosyllabic $\mathrm{H}$ tone roots never take a schwa outside the progressive. Our intuition has been that the schwa appears in contexts where a contour tone would otherwise arise. Derivations with the verb /kùm/ 'touch' representating the orange and blue patterns show this relation in (36).
a. Bún á ¡kúmò lí kə̀báyn
'Bung touched the fufu.' (P3 DJ)
lá ykùm/ $\rightarrow$ á ykûm
$\rightarrow$ ó ykúmò
b. Bún à ykùmó kābáyn
'Bung touched the fufu.' (P3 CJ)
/à ykùm '/ $\rightarrow$ ว̀ ykŭm
$\rightarrow$ ̀̀ ykùmó

In (36a) the $\mathrm{H}$ tone of the /á/ DJ marker spreads onto the verb, creating an intermediate HL falling tone. Since falling tones are not allowed on roots, the "repair" is to insert a schwa to take the L part of the contour. 
Similarly, in (36b), when the suffixal $\mathrm{H}$ is assigned to the verb, this creates an intermediate LH rising tone. Again, a schwa is inserted, this time to take the $\mathrm{H}$ part of the LH contour.

Whether the schwa is epenthetic, as we have represented it in (36), or whether it represents a historical retention, there is a potential problem with the assumption that schwa appears as an automatic response to avoiding contours. Recall that the yellow pattern also introduces a schwa, but only in the affirmative singular imperative, exemplified in (37a).
a. kùmá kə̄báyn
/kùm 'l+/kàbáyn/ $\rightarrow$ kǔm kòbáyn $\rightarrow$ kùmó kābáyn
b. Bún á né kùm kə̄báyn 'Bung will touch the fufu.' (F2)
/kùm '/ +/kòbáyn/ $\rightarrow$ kùm + kâbáyn $\rightarrow$ kùm kōbáyn

While we have given the same derivation in (37a) as was seen in (36b), the question is why we get a different result in (37b) and every other yellow cell. In this derivation the suffixal $\mathrm{H}$ does not get assigned to the verb root, but rather to the following prefix k̀े-, thereby producing an intermediate HL falling tone. As shown by Hyman (1979) and Akumbu (2019), a L-HL-H sequence is simplified to L-M-H by a general contour simplification process. ${ }^{19}$ What this shows is that the appearance of a schwa appears to be partly phonologically and partly morphologically conditioned. One way to accomplish this is via a "cophonology" approach (Inkelas \& Zoll 2007). In the P3 and the affirmative singular imperative, inserting a schwa is chosen as a better repair to the constraint against contours on root morphemes, while in the future (yellow) pattern, assigning the $\mathrm{H}$ to the prefix is the chosen resolution.

We suspect that other morphologically conditioned responses will be needed elsewhere, perhaps to account for why $\mathrm{H}$ tone spreading converts the $\mathrm{P} 1$ and $\mathrm{P} 2$ markers /yì/ and /tà/ to $y \hat{\imath}$ and tâ by $\mathrm{H}$ tone spreading, while the F2 and F3 markers /nè/ and /lù/ instead become né and lù. We leave this issue for now to consider the more general question of how to assign the appropriate morphological marking to the right cells in the paradigm. Since much of the segmental marking is largely consistent (e.g. tense markers, negative markers, progressive nasal prefix, and schwa suffix), we will concentrate on tone, i.e. on the six color-coded patterns. We begin by noting that we have two extremes: Blue and orange cells are quite restricted, while green cells are quite general. It would seem therefore that we need to do two things. First, we need to isolate those cells for which a special statement will be needed. These can be considered the equivalent of tonal "exceptions". Second, we can also isolate all of the green cells since their tone pattern is totally predictable. In previous work by the second author (e.g. Hyman 2016) the strategy pursued has been to first assign the general patterns, here the progressive (green), then look at the remainder to assign the next most general pattern among the non-progressives, then assign the next most general pattern, and so on. The idea is that by going from general to specific, the assignments may be simpler to state, the last assignment being the elsewhere case. The opposite strategy is also possible, where the most specific and unpredictable patterns are first assigned, leaving the more and more general ones to be accounted for next. In this approach the progressive would become the default tone pattern. ${ }^{20}$

It seems to us that the most likely approach would be an OT-style account ranking the tone assignments by morphosyntactic feature combinations. This too is not an easy task, but at least it is coherent: while the

${ }^{19}$ This same process is responsible for the $\mathrm{M}$ tone prefix found after monosyllabic / $\mathrm{H} /$ verbs in the grey pattern: /Bún yì lám kàbáyn/ $\rightarrow$ Búy yì lăm kàbáyn $\rightarrow$ Búy yì làm ' kàbáyn $\rightarrow$ Búy yì làm kâbáyn $\rightarrow$ Bún yì làm kābáyn 'Bung cooked the fufu' (P1). We are not proposing that so many steps are needed in such a derivation, only that the $\mathrm{H}$ of /lám/ has to shift onto the $\mathrm{L}$ prefix to derive the $\mathrm{M}$ tone. Bisyllabic $\mathrm{H}$ tone verbs do not raise the $\mathrm{L}$ prefix to $\mathrm{M}$ in the grey pattern: Búy yì sàntá kàbáyn 'Bung sifted the fufu'.

${ }^{20}$ Babanki does not appear to lend itself to an assignment based on a layered morphological structure as Inkelas (2011: 75) proposes for Hausa. In that kind of approach, the tonal patterns would be assigned first to the innermost brackets, then to the next set of brackets, erasing the earlier assignment in case of conflict. Babanki seems rather to be more like the other cases discussed by Hyman (2016), where there is a paradigm of tone patterns dependent on combinations of features. 
single feature PROG(ressive) assigns an undominated tone pattern, overriding all others, certain morphosyntactic feature combinations will be very restricted, e.g. those requiring the blue and orange tone patterns. To show how this might be done we adopt the following "marked" privative features:

$\begin{array}{lll}\text { PROG } & : & \text { progressive } \\ \text { DJ } & : & \text { disjoint } \\ \text { NEG } & : & \text { negative } \\ \text { PST } & : & \text { past } \\ \text { FUT } & : & \text { future } \\ \text { SBJV } & : & \text { subjunctive (includes imperative plural, hortative, conditional) } \\ \text { IMP } & : & \text { imperative (singular) }\end{array}$

To these we need to add the tenses: P0, P1, P2, P3, F1, F2, F3. In order to see how these features might be applied to the Babanki data, consider the following table, where we indicate which feature combinations receive which tone pattern:

Table 8: Tone patterns by features (first attempt)

\begin{tabular}{|l|l|l|l|l|l|}
\hline Green & Orange & Blue & Gold & Yellow & Grey \\
\hline PROG & P0 DJ & P3 & SBJV F1 & FUT DJ & PAST \\
& P3 DJ & & & FUT NEG [-sbjv] & FUT \\
& & & & IMP F1 & \\
& & & & IMP NEG & \\
& & & & PAST SBJV & \\
\hline
\end{tabular}

In Table 8 the six patterns are ordered with the intended ranking such that green is highest ranked and grey is lowest. In fact, the intention is for grey to be the default or elsewhere case. Thus, everything to the right of the first column is non-progressive. As a result of the ranking, once orange has assigned its pattern to the P0 DJ and P3 DJ, the blue pattern can now be assigned without regard to any feature other than P3. Similarly gold has targeted only the F1 subjunctive, leaving the F2 and F3 subjunctives untouched. This leaves us with yellow and grey. Here we meet a problem that will require a choice. Since we have ranked yellow higher than grey we have to be sure that it doesn't misappropriate certain cells, particularly the negative (non-progressive) subjunctive F2 and F3. These must remain grey. In Table 8 we put a [-sbjv] place holder, which violates the privativity of the features in (38). If we had changed the rankings, as in Table 9, we run into a different problem:

Table 9: Tone patterns by features (second attempt)

\begin{tabular}{|c|c|c|c|c|c|}
\hline Green & Orange & Blue & Gold & Grey & Yellow \\
\hline PROG & $\begin{array}{l}\text { P0 DJ } \\
\text { P3 DJ }\end{array}$ & P3 & SBJV F1 & $\begin{array}{l}\text { PST IND } \\
\text { FUT CJ } \\
\text { SBJV } \\
\text { IMP F2, F3 }\end{array}$ & $\begin{array}{l}\text { FUT } \\
\text { IMP F1 } \\
\text { IMP NEG } \\
\text { PAST SBJV }\end{array}$ \\
\hline
\end{tabular}

Since SBJV F1 has already been assigned to gold, we can designate grey for the remaining affirmative and negative F2 and F3 subjunctives. However, we now need to refer to the "unmarked" value CJ in order not to assign grey to future DJ tenses. Since DJ was needed to assign the orange tone pattern, we have the equivalence of $[ \pm \mathrm{DJ}]$.

Both analyses thus have problems. ${ }^{21}$ Two potential solutions seem possible. One is to change the feature values. If we could refer to the DJ, indicative and imperative negatives as having a special feature $[+\mathrm{F}]$, this

\footnotetext{
${ }^{21} \mathrm{We}$ also haven't addressed the conditional negative which takes the same yellow tone pattern as the non-DJ indicative and imperative negatives.
} 
could be required in assigning the yellow pattern to them (as well as to the conditional negative), thereby eliminating the [-sbjv] in Table 7. Similarly, if we assigned a special feature to the future CJ and the F2 and F3 imperatives affirmative and subjunctive affirmative and negative, we could use that feature in Table 8. Perhaps there are other such ad hoc moves one could consider.

Another solution is to split up one or more of the columns. Since we would like to keep grey as the default, let's try modifying Table 9 by treating the CJ-like F2 and F3 non-indicatives as receiving their grey pattern first: $^{22}$

Table 10: Tone patterns by features (third attempt)

\begin{tabular}{|l|l|l|l|l|l|l|}
\hline Green & Orange & Blue & Gold & Grey & Yellow & Grey \\
\hline PROG & P0 DJ & P3 & SBJV F1 & IMP F2, F3 & FUT DJ & PST \\
& P3 DJ & & SBJV F2, F3 & $\begin{array}{l}\text { FUT NEG } \\
\text { IMP F1 } \\
\text { PAST SBJV }\end{array}$ & FUT \\
\hline
\end{tabular}

While perhaps not as aesthetic, splitting the grey pattern in two does allow us to simplify the yellow assignment considerably. Not only do we not need the [-sbjv], but also IMP NEG: This feature combination will be taken care of by IMP F1 (which will cover affirmative and negative) and FUT NEG (which will cover the IMP F2 and F3). The one detail we haven't accounted for is the yellow pattern of the conditional negative which, recall, is a periphrastic construction whose main verb could be considered nonsubjunctive. ${ }^{23}$

To conclude, we should perhaps mention still another strategy: Conflate two of the colors! As we have tried to indicate, the tonal patterns on the verb stem are very much determined by their tonal surroundings. The yellow and gold patterns look very similar except that the latter has a preverbal $\mathrm{H}$ tone prefix, which is lacking in the yellow pattern. The above tables are designed only to account for the tones, not for the markers that occur before or after the verb stem. While we haven't pursued this or other conceivable approaches, we point this out for anyone who would like to try their hand at coming up with a more comprehensive account that includes these markers. Since we include all of the data we have considered in the appendices, we hope we have provided enough to work on there - but invite others to expand the coverage both in Babanki and in related languages in the future.

\section{Abbreviations and Symbols}

${ }^{\downarrow}$ Downstep, 1 PL First person plural, 2PL Second Person Plural, 3p Third Person Plural, 7, 19 Noun Classes, AFF Affirmative, AGR Agreement, C Consonant, CJ Conjoint, COMP Complementizer, DJ Disjoint, F1 Immediate Future Tense, F2 Hodiernal Future Tense, F3 Distant Past Tense, FUT Future, H High Tone, HORT Hortative, IMP Imperative, IND Indicative, IPFV Imperfective, L Low Tone, LTS Low Tone Spread, M Mid Tone, MCA Main Clause Affirmative, N Nasal, NEG Negative, P0 Present/Perfect tense, P1 Immediate Past Tense, P2 Hodiernal Past Tense, P3 Distant Past Tense, PFV Perfective, PL Plural, PRO Pronoun, PROG Progressive, PST Past, SBJV Subjunctive, SG Singular, SM Subject Marker, T Root tone (H or L), TAM Tense Aspect Mood, V Vowel.

22 The reasons for favoring grey to be the default are, first, that it realizes the unmarked feature values "indicative" and "CJ", and second, that it is morphologically unmarked, being the only pattern not to involve a suffix (cf. Table 6).

${ }^{23}$ Note that the $\mathrm{H}$ tone of $d i$ ? from in the F1 suggests a $\mathrm{H}$ marker preceding the input verb di? 'be', thus making it fall into line with the gold subjunctive cells. The F2 and F3 nè dì and lù dì look like they carry the grey pattern. Thus, while the auxiliary verb shows the expected subjunctive pattern, the main verb shows a different (yellow) one. 


\section{Appendix 1. Affirmative indicative verb forms}

1. Perfective (CJ) 2. Perfective (DJ)

\section{$\mathbf{L}+\mathbf{L}-\mathbf{T}$}

Búy zhì kābáyn

Bún làm kābáyn

P0 Bún shìtá kàbáyn

Bún sàntá kàbáyn

Bún lè kàbáyn

Bún kùm kə̀báyn

Bún shìsò kə̀báyn

Bún lìmsà kàbáyn

\section{$\mathbf{L}+\mathbf{L}-\mathbf{T}$}

Búy yì zhì kōbáyn

Bún yì làm kābáyn

P1 Bún yì shìtá kàbáyn

Bún yì sàntá kàbáyn

Bún yì lè kàbáyn

Bún yì kùm kàbáyn

Búy yì shìsà kàbáyn

Bún yì lìmsà kàbáyn

\section{$\mathbf{L}+\mathbf{L}-\mathbf{T}$}

Búy tà zhì kābáyn

Bún tò làm kābáyn

P2 Bún tò shìtó kàbáyn

Búy tò sàntá kàbáyn

Bún tò lè kàbáyn

Bún tò kùm kàbáyn

Bún tà shìsà kàbáyn

Bún tò lìmsò kàbáyn

\section{$\mathbf{L}+\mathbf{L}-\partial ́$}

Bún ว̀ nzhì kə̄báyn

Búy ว̀ nlàm kābáyn

P3 Bún à nshìtá kàbáyn

Bún ò nsə̀ntá kàbáyn

Búy ว̀ nlèé kābáyn

Bún ว̀ ykùmá kābáyn

Bún à nshìsá kābáyn

Bún ว̀ nlìmsá kābáyn

\section{$\mathbf{L}+\mathbf{L}-\mathbf{T}$}

Bún à zhì kābáyn

Bún à làm kōbáyn

F1 Bún à shìtó kàbáyn

Bún à sòntá kàbáyn

Bún à lè kàbáyn

Bún à kùm kə̀báyn

Bún à shìsà kàbáyn

Búy à lìmsò kàbáyn
á+H-T+'lí

Búy á zhá 'lí kàbáyn

Bún á lám ‘lí kòbáyn

Bún á shítá 'lí kàbáyn

Bún á sántá 'lí kàbáyn

Bún á léè lí kàbáyn

Búy á kúmò lí kàbáyn

Bún á shís lí kàbáyn

Bún ó límsò lí kə̀báyn

L+L-T

Búy á yî zhì kə̄báyn

Bún ó yî làm kābáyn

Bún á yî shìtá kàbáyn

Bún á yî sàntá kàbáyn

Bún ó yî lè kàbáyn

Bún á yî kùm kàbáyn

Bún ó yî shìs ̀̀̀báyn

Bún á yî lìmsà kə̀báyn

L+L-T

Búy á tô zhà kābáyn

Búy á tâ làm kābáyn

Búy á tô shìtá kàbáyn

Bún á tâ sàntá kàbáyn

Bún á tô lè kàbáyn

Bún á tô kùm kàbáyn

Bún á tâ shìsà kàbáyn

Búy á tâ lìmsà kàbáyn

á+H-T+'lí

Búy á nzhí 'lí kàbáyn

Bún á nlám لlí kàbáyn

Búy á nshítá ‘lí kàbáyn

Bún á nsántá ‘lí àbáyn

Búy á nléè lí kàbáyn

Búy á ykúmà lí kàbáyn

Bún á nshísà lí kàbáyn

Bún á nlímsà lí kàbáyn

\section{L+T-H}

Búy á 'zhí kābáyn

Bún á 'lám kōbáyn

Búy á `shító kə̄báyn

Búy á `sóntó kōbáyn

Búy á lè kə̄báyn

Búy á kùm kōbáyn

Búy á shìsó kābáyn

Búy á lìmsá kābáyn
3. Progressive

Glosses

H+T-̀̀

Búy zhúi kòbáyn

Bún lámó kàbáyn

Búy shítò kàbáyn

Búy sántà kàbáyn

Bún lèè kòbáyn

Bún kùmò kàbáyn

Bún shìs̀̀ kə̀báyn

Búy lìmsà kàbáyn

H+T-̀̀

Bún yǐ nzhít kàbáyn

Búy yǐ nlámá kàbáyn

Bún yǐ nshítà kàbáyn

Bún yǐ nsántà kàbáyn

Bún yǐ nlèè kàbáyn

Bún yǐ Đkùmò kə̀báyn

Bún yǐ nshìsò kòbáyn

Bún yǐ nlìmsà kàbáyn

H+T-̀̀

Bún tǒ nzhít kàbáyn

Bún tǎ nlámá kàbáyn

Bún tă nshítò kàbáyn

Búy tǒ nsántò kàbáyn

Bún tŏ nlèè kàbáyn

Bún tǒ ykùmò kàbáyn

Búy tǎ nshìsà kàbáyn

Bún tǎ nlìmsò kàbáyn

H+T-̀े

Bún ว̀ nzhút kə̀báyn

Bún à nlámó kàbáyn

Bún à nshítà kàbáyn

Bún ว̀ nsóntà kàbáyn

Bún ว̀ nlèè kàbáyn

Bún à ykùmò kə̀báyn

Bún ว̀ nshìsà kàbáyn

Bún à nlìmsà kàbáyn

\section{H+T-̀̀}

Búy á nzhít kàbáyn

Bún á nlámó kàbáyn

Bún á nshítò kàbáyn

Bún á nsántà kàbáyn

Bún á nlèè kàbáyn

Búy á ykùmò kàbáyn

Bún á nshìsà kàbáyn

Búy á nlìmsò kòbáyn
Bung has eaten/is eating fufu

... has cooked/is cooking ...

... has collected/is collecting ...

... has sifted/is sifting ...

... has lost/is losing ...

... has touched/is touching ...

... has removed/was removing ... ... has heated/is heating ...

Bung ate/was eating fufu

... cooked/was cooking ...

... collected/was collecting ...

... sifted/was sifting ...

... lost/was losing ...

... touched/was touching ...

... removed/was removing ... ... heated/was heating ...

Bung ate/was eating fufu

... cooked/was cooking ...

... collected/was collecting ...

... sifted/was sifting ...

... lost/was losing ...

... touched/was touching ...

... removed/was removing ... ... heated/was heating ...

Bung ate/was eating fufu

... cooked/was cooking ...

... collected/was collecting ...

... sifted/was sifting ...

... lost/was losing ...

... touched/was touching ...

... removed/was removing ... ... heated/was heating ...

Bung will eat/be eating fufu

... will cook/be cooking ...

... will collect/be collecting ...

... will sift/be sifting ...

... will lose/be losing ...

... will touch/be touching ...

... will remove/be removing ... ... will heat/be heating ... 


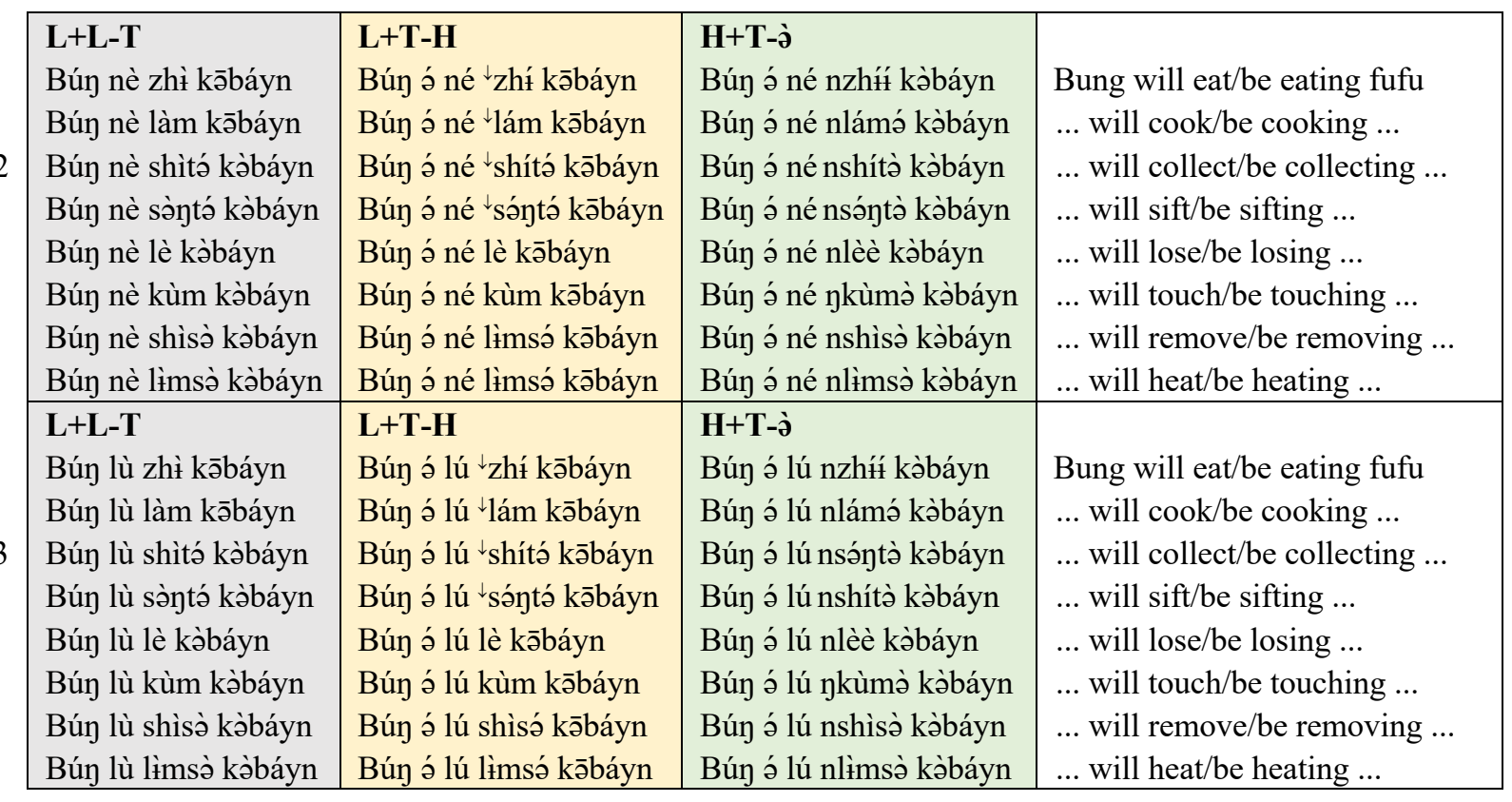

\section{Appendix 2. Negative indicative verb forms}

Perfective NEG

\section{L+L-T}

Búy á kó zhì kābáyn

Bún á kó làm kābáyn

P0

Bún á kó shìtá kàbáyn

Búy á kó sàntá kàbáyn

Búy á kó lè kàbáyn

Bún á kó kùm kàbáyn

Búy á kó shìsà kàbáyn

Bún á kó lìmsà kàbáyn

\section{L+L-T}

Bún á kó yì zhì kābáyn

Búy á kó yì làm kābáyn

P1 Bún á kó yì shìtá kàbáyn

Bún á kó yì sə̀ytá kə̀báyn

Bún á kó yì lè kàbáyn

Búy á kó yì kùm kàbáyn

Bún á kó yì shìsà àbáyn

Bún á kó yì lìmsà kə̀báyn

\section{$\mathbf{L}+\mathbf{L}-\mathbf{T}$}

Bún á kó tò zhì kābáyn

Bún ó kó tà làm kābáyn

P2 Bún á kó tò shìtá kàbáyn

Bún á kó tà sàntá kàbáyn

Bún á kó tà lè kàbáyn

Búy á kó tà kùm kàbáyn

Bún á kó tà shìsà kàbáyn

Búy á kó tà lìmsà kàbáyn
Progressive NEG

Glosses

\section{H+T-̀̀}

Bún á kó ${ }^{\downarrow}$ zhú kàbáyn

Bún á kó 'lámá kàbáyn

Bún á kó `shítà kàbáyn

Bún á kó 'sántà kàbáyn

Bún á kó lèè kàbáyn

Bún á kó kùmà kàbáyn

Búy á kó shìsò kàbáyn

Bún á kó lìmsà kàbáyn

\section{$\mathbf{H}+\mathbf{T}-\dot{\partial}$}

Búy á kó yǐ nzhít kàbáyn

Bún á kó yǐ nlámá kàbáyn

Bún á kó yǐ nshítò kàbáyn

Búy á kó yǐ nsántà kə̀báyn

Bún á kó yǐ nlèè kàbáyn

Bún á kó yĩ ykùmà kàbáyn

Bún á kó yǐ nshìsà kàbáyn

Bún á kó yĩ nlìmsà kə̀báyn

\section{$\mathbf{H}+\mathbf{T}-\grave{\partial}$}

Búy á kó tă nzhíz kàbáyn

Bún á kó tă nlámá kàbáyn

Bún á kó tǒ nshítà kə̀báyn

Bún á kó tǒ nsántà kə̀báyn

Bún á kó tă nlèè kàbáyn

Bún á kó tǎ ykùmà kàbáyn

Bún á kó tă nshìsà kàbáyn

Búy á kó tă nlìmsà kàbáyn
Bung has not eaten/is not eating fufu

Bung has not cooked/is not cooking fufu

Bung has not collected/is not collecting fufu

Bung has not sifted/is not sifting fufu

Bung has not lost/is not losing fufu

Bung has not touched/is not touching fufu

Bung has not remove/is not removing fufu

Bung has not heated/is not heating fufu

Bung did not eat/was not eating fufu

Bung did not cook/was not cooking fufu

Bung did not collect/was not collecting fufu

Bung did not sift/was not sifting fufu

Bung did not lose/was not losing fufu

Bung did not touch/was not touching fufu

Bung did not remove/was not removing fufu

Bung did not heat/was not heating fufu

Bung did not eat/was not eating fufu

Bung did not cook/was not cooking fufu

Bung did not collect/was not collecting fufu

Bung did not sift/was not sifting fufu

Bung did not lose/was not losing fufu

Bung did not touch/was not touching fufu

Bung did not remove/was not removing fufu

Bung did not heat/was not heating fufu 


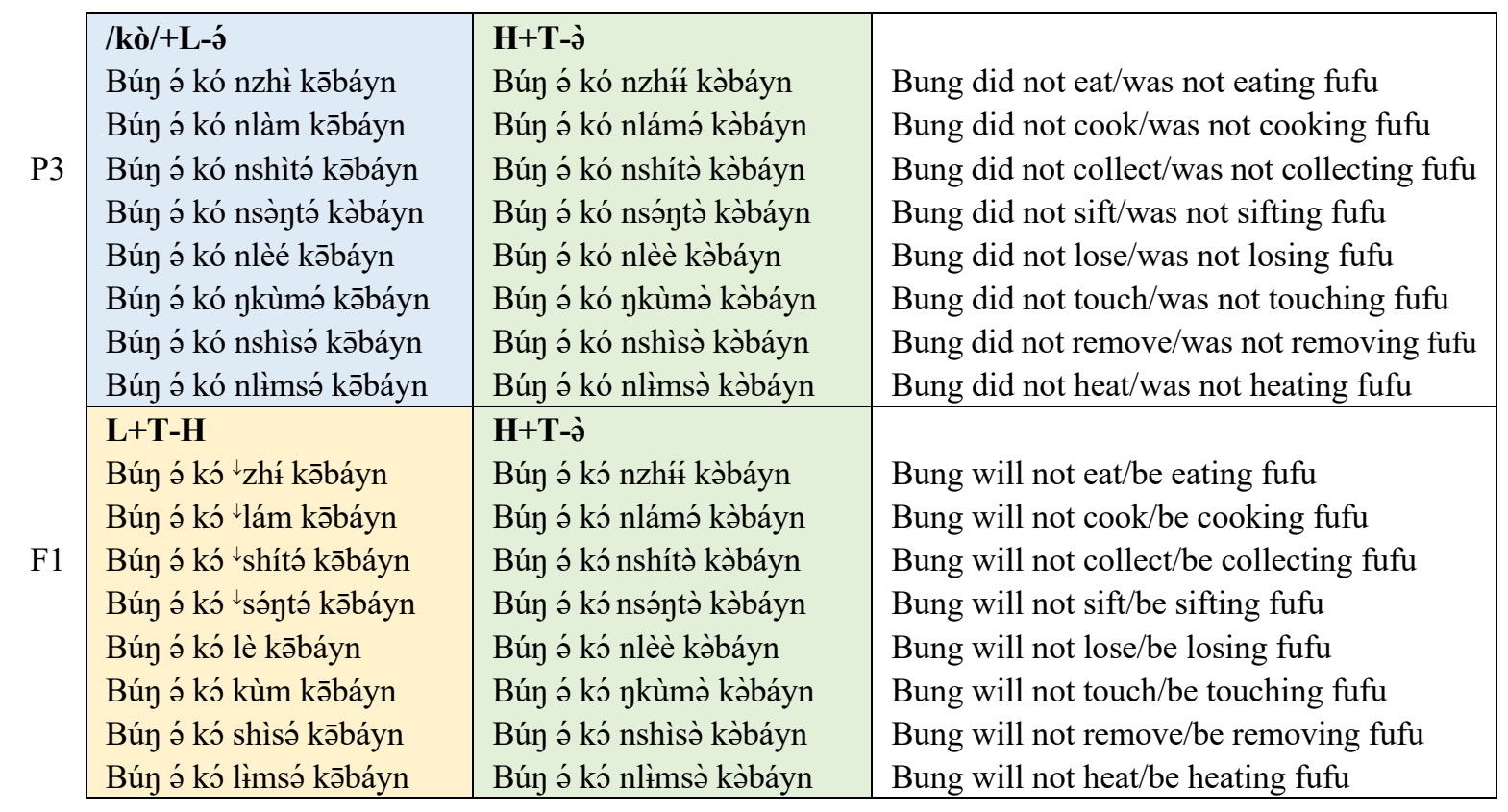

\section{Appendix 3. Affirmative imperative singular verb forms}

\begin{tabular}{|c|c|c|c|}
\hline & tive & Progressive & Gloss \\
\hline $\mathrm{F} 1$ & $\begin{array}{l}\text { L+T-H } \\
\text { zhí kābáyn } \\
\text { lám kābáyn } \\
\text { shítá kābáyn } \\
\text { sóntá kābáyn } \\
\text { lèé kābáyn } \\
\text { kùmá kābáyn } \\
\text { shìsó kābáyn } \\
\text { lìmsá kə̄báyn }\end{array}$ & 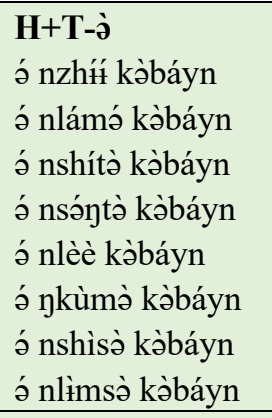 & $\begin{array}{l}\text { eat/be eating fufu! } \\
\text { cook/be cooking fufu! } \\
\text { collect/be collecting fufu! } \\
\text { sift/be sifting fufu! } \\
\text { lose/be losing fufu! } \\
\text { touch/be touching fufu! } \\
\text { remove/be removing fufu! } \\
\text { heat/be heating fufu! }\end{array}$ \\
\hline $\mathrm{F} 2$ & $\begin{array}{l}\text { L+L-T } \\
\text { nè zhì kābáyn } \\
\text { nè làm kə̄báyn } \\
\text { nè shìtá kə̀báyn } \\
\text { nè sə̀ntó kòbáyn } \\
\text { nè lè kàbáyn } \\
\text { nè kùm kàbáyn } \\
\text { nè shìs̀̀ kə̀báyn } \\
\text { nè lìmsà kàbáyn }\end{array}$ & $\begin{array}{l}\text { H+T-à } \\
\text { né nzhíf́ kàbáyn } \\
\text { né nlámá kābáyn } \\
\text { né nshítà kàbáyn } \\
\text { né nsóntà kàbáyn } \\
\text { né nlèè kàbáyn } \\
\text { né ykùmà kàbáyn } \\
\text { né nshìsà kàbáyn } \\
\text { né nlìmsà kàbáyn }\end{array}$ & $\begin{array}{l}\text { eat/be eating fufu! } \\
\text { cook/be cooking fufu! } \\
\text { collect/be collecting fufu! } \\
\text { sift/be sifting fufu! } \\
\text { lose/be losing fufu! } \\
\text { touch/be touching fufu! } \\
\text { remove/be removing fufu! } \\
\text { heat/be heating fufu! }\end{array}$ \\
\hline $\mathrm{F} 3$ & 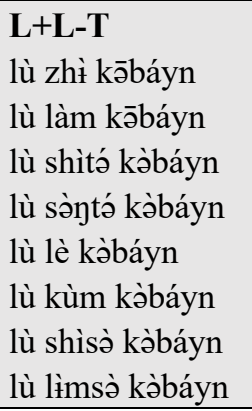 & 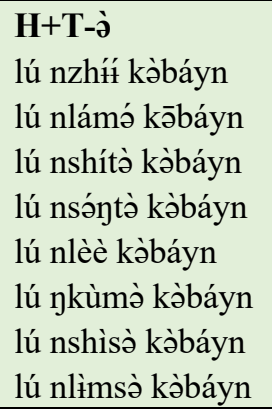 & $\begin{array}{l}\text { eat/be eating fufu! } \\
\text { cook/be cooking fufu! } \\
\text { collect/be collecting fufu! } \\
\text { sift/be sifting fufu! } \\
\text { lose/be losing fufu! } \\
\text { touch/be touching fufu! } \\
\text { remove/be removing fufu! } \\
\text { heat/be heating fufu! }\end{array}$ \\
\hline
\end{tabular}




\section{Appendix 4. Affirmative imperative plural verb forms}

\begin{tabular}{|c|c|c|c|}
\hline & Perfective AFF & Progressive AFF & Gloss \\
\hline $\mathrm{F} 1$ & 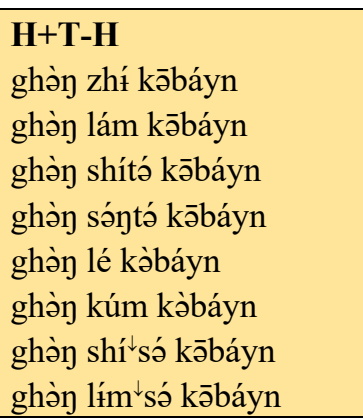 & 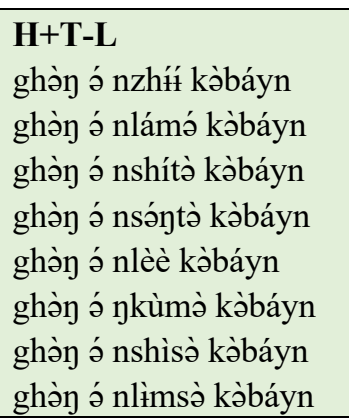 & $\begin{array}{l}\text { eat/be eating fufu! } \\
\text { cook/be cooking fufu! } \\
\text { collect/be collecting fufu! } \\
\text { sift/be sifting fufu! } \\
\text { lose/be losing fufu! } \\
\text { touch/be touching fufu! } \\
\text { remove/be removing fufu! } \\
\text { heat/be heating fufu! }\end{array}$ \\
\hline F2 & 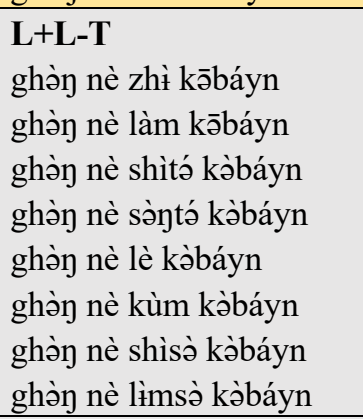 & 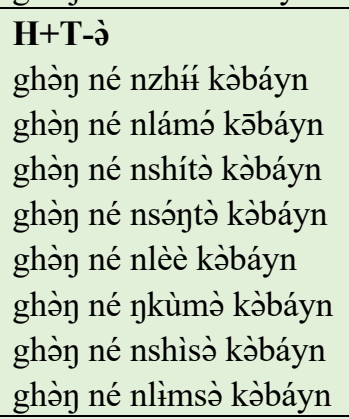 & $\begin{array}{l}\text { eat/be eating fufu! } \\
\text { cook/be cooking fufu! } \\
\text { collect/be collecting fufu! } \\
\text { sift/be sifting fufu! } \\
\text { lose/be losing fufu! } \\
\text { touch/be touching fufu! } \\
\text { remove/be removing fufu! } \\
\text { heat/be heating fufu! }\end{array}$ \\
\hline $\mathrm{F} 3$ & 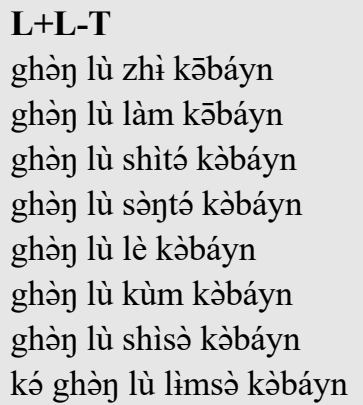 & 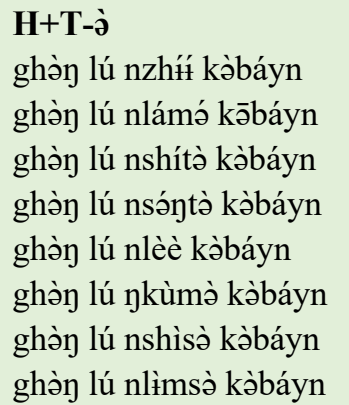 & $\begin{array}{l}\text { eat/be eating fufu! } \\
\text { cook/be cooking fufu! } \\
\text { collect/be collecting fufu! } \\
\text { sift/be sifting fufu! } \\
\text { lose/be losing fufu! } \\
\text { touch/be touching fufu! } \\
\text { remove/be removing fufu! } \\
\text { heat/be heating fufu! }\end{array}$ \\
\hline
\end{tabular}

\section{Appendix 5. Affirmative hortative verb forms}

\begin{tabular}{|c|c|c|}
\hline Perfective AFF & Progressive AFF & Gloss \\
\hline 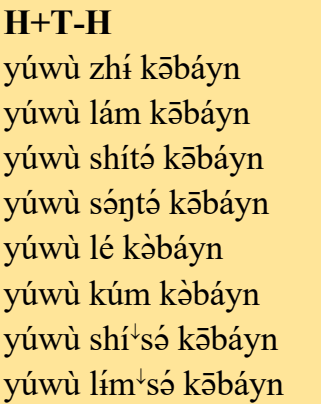 & 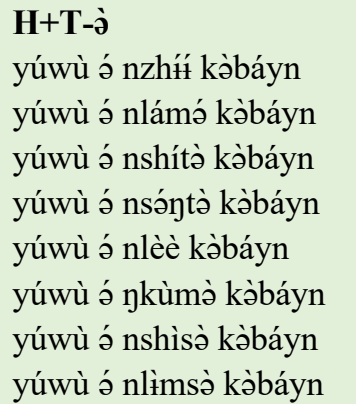 & $\begin{array}{l}\text { let's eat/be eating fufu! } \\
\text { let's cook/be cooking fufu! } \\
\text { let's collect/be collecting fufu! } \\
\text { let's sift/be sifting fufu! } \\
\text { let's lose/be losing fufu! } \\
\text { let's touch/be touching fufu! } \\
\text { let's remove/be removing fufu! } \\
\text { let's heat/be heating fufu! }\end{array}$ \\
\hline $\begin{array}{l}\text { L+L-T } \\
\text { yúwù nè zhì kābáyn } \\
\text { yúwù nè làm kābáyn } \\
\text { yúwù nè shìtá kòbáyn } \\
\text { yúwù nè sòntá kòbáyn } \\
\text { yúwù nè lè kàbáyn } \\
\text { yúwù nè kùm kòbáyn }\end{array}$ & 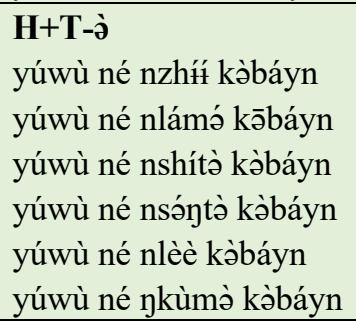 & $\begin{array}{l}\text { let's eat/be eating fufu! } \\
\text { let's cook/be cooking fufu! } \\
\text { let's collect/be collecting fufu! } \\
\text { let's sift/be sifting fufu! } \\
\text { let's lose/be losing fufu! } \\
\text { let's touch/be touching fufu! }\end{array}$ \\
\hline
\end{tabular}




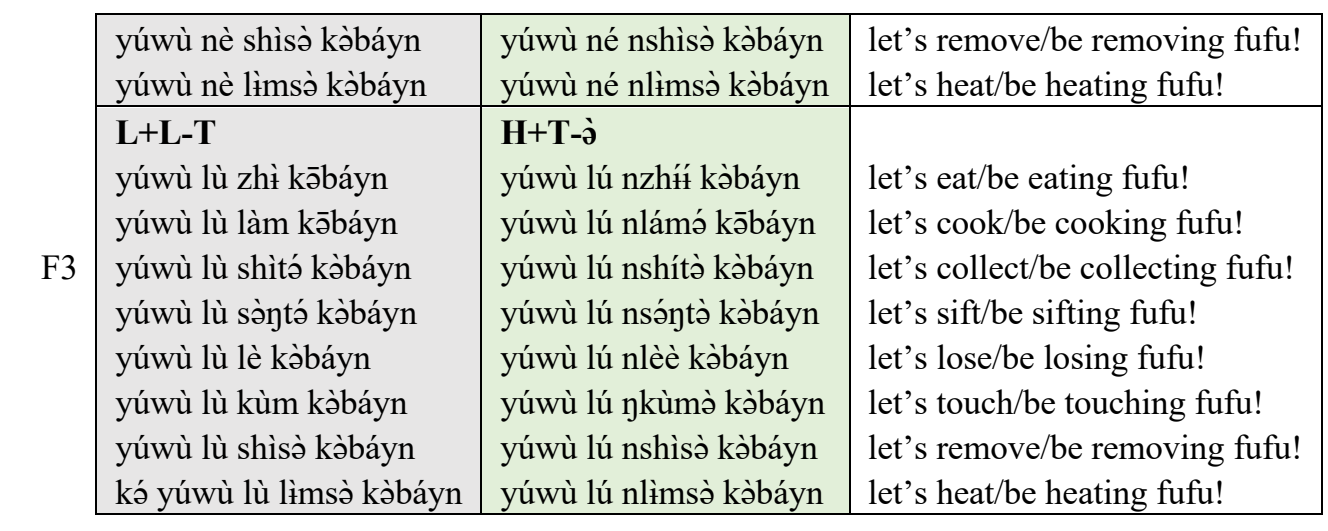

\section{Appendix 6. Affirmative subjunctive verb forms}

\section{Perfective AFF}

\section{H+T-H}

... lá yúwù zhí kə̄báyn

... lá yúwù lám kə̄báyn

F1 ... lá yúwù shító kōbáyn

... lá yúwù sóntó kōbáyn

... lá yúwù lé kàbáyn

... lá yúwù kúm kàbáyn

... lá yúwù shí'sá kə̄báyn

... lá yúwù límsá kə̄báyn

$\mathbf{L}+\mathbf{L}-\mathbf{T}$

F2

... lá yúwù nè zhì kābáyn

... lá yúwù nè làm kōbáyn

... lá yúwù nè sàntó kàbáyn

... lá yúwù nè lè kə̀báyn

... lá yúwù nè kùm kàbáyn

... lá yúwù nè shìs ̀̀̀ kábáyn

... lá yúwù nè lìmsà kàbáyn

L+L-T

... lá yúwù lù zhì kābáyn

... lá yúwù lù làm kə̄báyn

F3

... lá yúwù lù shìtá kàbáyn

... lá yúwù lù sàntá kàbáyn

... lá yúwù lù lè kàbáyn

... lá yúwù lù kùm kàbáyn

... lá yúwù lù shìsò kàbáyn ... lá yúwù lù lìmsà kàbáyn
Progressive AFF

H+T-̀̀

... lá yúwù á nzhík kàbáyn

... lá yúwù ó nlámó kàbáyn

... lá yúwù ó nshítà kàbáyn

... lá yúwù á nsántà kàbáyn

... lá yúwù á nlèè kòbáyn

... lá yúwù á ykùmà kàbáyn

... lá yúwù á nshìsò kə̀báyn ... lá yúwù á nlìmsà kàbáyn

H+T-̀̀

... lá yúwù né nzhí kàbáyn

... lá yúwù né nlámá kàbáyn

... lá yúwù né nshítà kàbáyn

... lá yúwù né nsántà kàbáyn

... lá yúwù né nlèè kàbáyn

... lá yúwù né ykùmà kàbáyn

... lá yúwù né nshìsò kàbáyn lá yúwù né nlìmsà kòbáyn

H+T-̀े

... lá yúwù lú nzhút kòbáyn

... lá yúwù lú nlámá kàbáyn

... lá yúwù lú nshítà kàbáyn

... lá yúwù lú nsóntà kàbáyn

... lá yúwù lú nlèè kàbáyn

... lá yúwù lú ykùmò kàbáyn

... lá yúwù lú nshìsà kàbáyn .. lá yúwù lú nlìmsò kàbáyn
Gloss

... that we eat fufu!

... that we cook fufu!

... that we collect fufu!

... that we sift fufu!

... that we lose fufu!

... that we touch fufu!

... that we remove fufu! ... that we heat fufu!

... that we eat fufu!

... that we cook fufu!

... that we collect fufu!

... that we sift fufu!

... that we lose fufu!

... that we touch fufu!

... that we remove fufu! ... that we heat fufu!

... that we eat fufu!

... that we cook fufu!

... that we collect fufu!

... that we sift fufu!

... that we lose fufu!

... that we touch fufu!

... that we remove fufu! that we heat fufu!

\section{Appendix 7. Affirmative conditional verb forms}

Perfective AFF

H+T-H

sótsèn Bún zhí kābáyn ... sótsèn Bún lám kə̄báyn ...

F1 sátsèn Búy shítá kə̄báyn ... sátsèn Bún sáytá kābáyn ... sátsèn Bún lé kàbáyn ... sátsèn Bún kúm kàbáyn ...

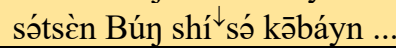

Progressive AFF

H+T-̀̀ sátsèn Búy á nzhít kə̀báyn ... sátsèn Búy á nlámá kàbáyn ... sátsc̀n Búy á nshítò kàbáyn ... sátsèn Bún á nsántà kàbáyn ... sátsèn Bún á nlèè kàbáyn ... sátsèn Búy ó ykùmò kàbáyn ... sátsèn Bún á nshìsò kàbáyn ...
Gloss

If Bung eats fufu ...! If Bung cooks fufu ...! If Bung collects fufu ...! If Bung sifts fufu ...! If Bung loses fufu ...! If Bung touches fufu ...! If Bung removes fufu ...! 
F2

3

P0

P1

P2

Bi

sátsc̀n Búy lím sá kābáyn ...

L+L-T

sátsèn Búy nè zhì kābáyn ... sátsèn Búy nè làm kābáyn ... sátsc̀n Búy nè shìtá kàbáyn ... sátsèn Búy nè sòntó kàbáyn ... sátsèn Bún nè lè kàbáyn ... sátsc̀n Búy nè kùm kàbáyn ... sátsc̀n Búy nè shìsò kàbáyn ... sátsc̀n Búy nè lìmsà kàbáyn ...

$\mathbf{L}+\mathbf{L}-\mathbf{T}$

sátsèn Búy lù zhì kōbáyn ... sátsc̀n Búy lù làm kōbáyn ... sátsèn Búy lù shìtá kàbáyn ... sátsèn Búy lù sàntá kàbáyn ... sátsèn Bún lù lè kàbáyn ... sátsc̀n Bún lù kùm kòbáyn .. sátsc̀n Búy lù shìsà kàbáyn ... sátsc̀n Bún lù lìmsà kàbáyn ...
Perfective AFF

\section{L+T-H}

Bún tí ${ }^{\downarrow}$ zhí kə̄báyn ...

Bún tí 'lám kə̄báyn ...

Bún tí ${ }^{\downarrow}$ shítá kābáyn ...

Bún tí ${ }^{\downarrow}$ sántó kābáyn ...

Bún tí lè kābáyn ...

Búy tí kùm kābáyn ...

Bún tí shìsá kə̄báyn ...

Búy tí lìmsó kōbáyn ...

\section{L+T-H}

Bún yì tí ${ }^{\downarrow}$ zhí kōbáyn ...

Bún yì tí ${ }^{\downarrow}$ lám kābáyn ...

Bún yì tí ${ }^{\downarrow}$ shító kābáyn ...

Bún yì tí ${ }^{\downarrow}$ sóntá kōbáyn ...

Bún yì tí lè kə̄báyn ...

Bún yì tí kùm kōbáyn ...

Bún yì tí shìsá kābáyn ...

Bún yì tí lìmsá kābáyn ...

\section{L+T-H}

Bún tò tí ${ }^{\downarrow} z h i ́$ kōbáyn ... Bún tò tí ${ }^{\downarrow}$ lám kābáyn ...

Bún tò tí ${ }^{\downarrow}$ shító kābáyn ...

Búy tò tí ${ }^{\downarrow}$ sántá kə̄báyn ...

Bún tà tí lè kābáyn ...

Bún tò tí kùm kōbáyn ...

Bún tà tí shìsá kābáyn ...

Bún tò tí lìmsá kābáyn ...

\begin{tabular}{|c|c|}
\hline sátsèn Búy á nlìmsà kàbáyn ... & If Bung heats fufu ...! \\
\hline 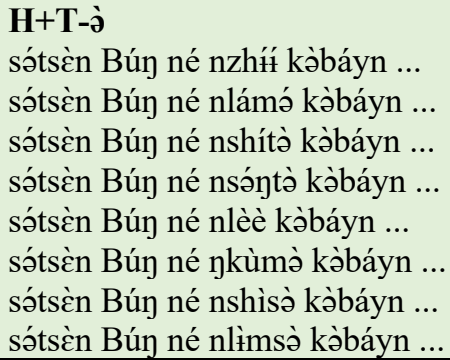 & $\begin{array}{l}\text { If Bung eats fufu ...! } \\
\text { If Bung cooks fufu ...! } \\
\text { If Bung collects fufu ...! } \\
\text { If Bung sifts fufu ...! } \\
\text { If Bung loses fufu ...! } \\
\text { If Bung touches fufu ...! } \\
\text { If Bung removes fufu ...! } \\
\text { If Bung heats fufu ...! }\end{array}$ \\
\hline 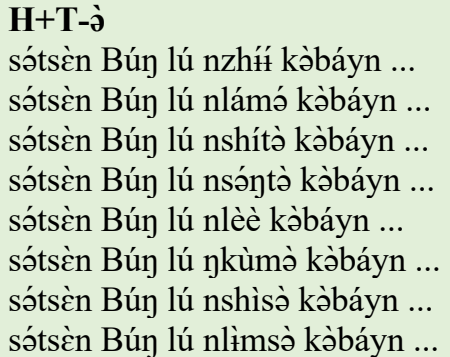 & $\begin{array}{l}\text { If Bung eats fufu ...! } \\
\text { If Bung cooks fufu ...! } \\
\text { If Bung collects fufu ...! } \\
\text { If Bung sifts fufu ...! } \\
\text { If Bung loses fufu ...! } \\
\text { If Bung touches fufu ...! } \\
\text { If Bung removes fufu ...! } \\
\text { If Bung heats fufu ...! }\end{array}$ \\
\hline
\end{tabular}

\section{Appendix 8. Affirmative past conditional verb forms}

Progressive AFF

\section{H+T-̀̀}

Búy tí nzhíí kàbáyn ...

Bún tí nlámó kàbáyn ...

Bún tí nshítว̀ kàbáyn ...

Bún tí nsóntà kàbáyn ...

Bún tí nlèè kàbáyn ...

Bún tí ๆkùmò kə̀báyn ...

Bún tí nshìsà kə̀báyn ...

Bún tí nlìmsà kə̀báyn ...

\section{H+T-̀̀}

Búy yì tí nzhít kàbáyn ...

Búy yì tí nlámá kə̀báyn ..

Bún yì tí nshítò kàbáyn ...

Bún yì tí nsánt̀̀ kàbáyn ...

Bún yì tí nlèè kàbáyn ...

Bún yì tí ykùmò kòbáyn ...

Búy yì tí nshìsà kàbáyn ...

Bún yì tí nlìmsà kàbáyn ...

\section{H+T-̀े}

Bún tò tí nzhít kə̀báyn ...

Bún tò tí nlámó kòbáyn ...

Bún tò tí nshít̀̀ kòbáyn ...

Bún tà tí nsántà kàbáyn ...

Bún tò tí nlèè kàbáyn ...

Bún tò tí jkùmò kàbáyn ...

Bún tò tí nshìsò kàbáyn ...

Bún tò tí nlìmsò kàbáyn ...
Gloss

If Bung had eaten fufu ...!

If Bung had cooked fufu ...!

If Bung had collected fufu ...!

If Bung had sifted fufu ...!

If Bung had lost fufu ...!

If Bung had touched fufu ...!

If Bung had removed fufu ...!

If Bung had heated fufu ...!

If Bung had eaten fufu ...!

If Bung had cooked fufu ...!

If Bung had collected fufu ...!

If Bung had sifted fufu ...!

If Bung had lost fufu ...!

If Bung had touched fufu ...!

If Bung had removed fufu ...!

If Bung had heated fufu ...!

If Bung had eaten fufu ...!

If Bung had cooked fufu ...!

If Bung had collected fufu ...!

If Bung had sifted fufu ...!

If Bung had lost fufu ...!

If Bung had touched fufu ...!

If Bung had removed fufu ...!

If Bung had heated fufu ...! 


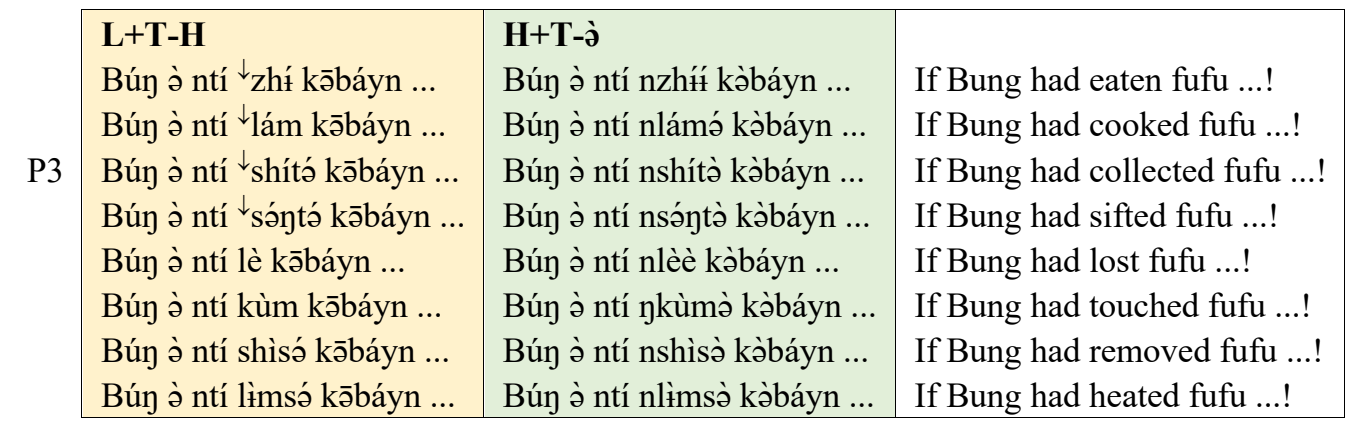

\section{Appendix 9. Negative imperative singular verb forms}

\begin{tabular}{|c|c|c|c|}
\hline & Perfective & Progressive & Gloss \\
\hline F1 & $\begin{array}{l}\text { L+T-H } \\
\text { ká }{ }^{\downarrow} \text { zhí kə̄báyn } \\
\text { ká }{ }^{\downarrow} \text { lám kə̄báyn } \\
\text { ká }{ }^{\downarrow} \text { shítá kə̄báyn } \\
\text { ká }{ }^{\downarrow} \text { sántá kōbáyn } \\
\text { ká lè kə̄báyn } \\
\text { ká kùm kə̄báyn } \\
\text { ká shìsá kə̄báyn } \\
\text { ká lìmsá kə̄báyn }\end{array}$ & 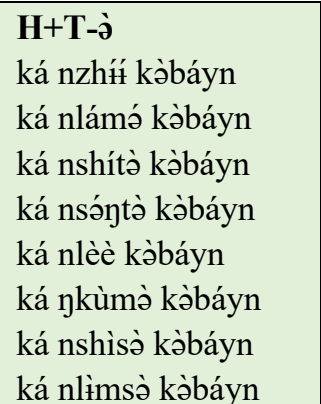 & $\begin{array}{l}\text { don't eat/be eating fufu! } \\
\text { don't cook/be cooking fufu! } \\
\text { don't collect/be collecting fufu! } \\
\text { don't sift/be sifting fufu! } \\
\text { don't lose/be losing fufu! } \\
\text { don't touch/be touching fufu! } \\
\text { don't remove/be removing fufu! } \\
\text { don't heat/be heating fufu! }\end{array}$ \\
\hline $\mathrm{F} 2$ & $\begin{array}{l}\text { L+T-H } \\
\text { ká né }{ }^{\downarrow} \text { zhí kābáyn } \\
\text { ká né }{ }^{\downarrow} \text { lám kābáyn } \\
\text { ká né }{ }^{\downarrow} \text { shítá kābáyn } \\
\text { ká né }{ }^{\downarrow} \text { sóntó kə̄báyn } \\
\text { ká né lè kābáyn } \\
\text { ká né kùm kābáyn } \\
\text { ká né shìsó kābáyn } \\
\text { ká né lìmsá kə̄báyn }\end{array}$ & 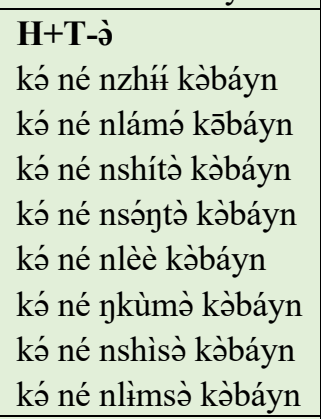 & $\begin{array}{l}\text { don't eat/be eating fufu! } \\
\text { don't cook/be cooking fufu! } \\
\text { don't collect/be collecting fufu! } \\
\text { don't sift/be sifting fufu! } \\
\text { don't lose/be losing fufu! } \\
\text { don't touch/be touching fufu! } \\
\text { don't remove/be removing fufu! } \\
\text { don't heat/be heating fufu! }\end{array}$ \\
\hline F3 & 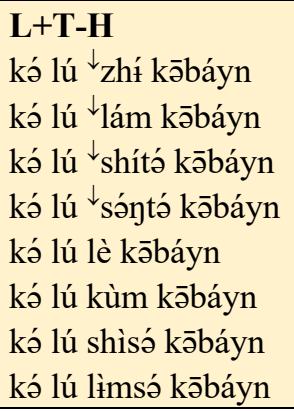 & 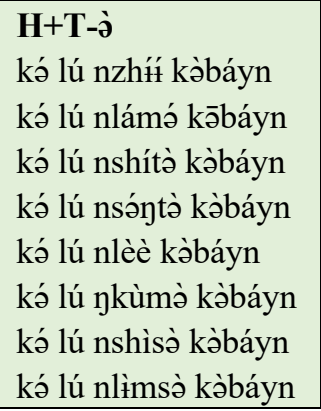 & $\begin{array}{l}\text { don't eat/be eating fufu! } \\
\text { don't cook/be cooking fufu! } \\
\text { don't collect/be collecting fufu! } \\
\text { don't sift/be sifting fufu! } \\
\text { don't lose/be losing fufu! } \\
\text { don't touch/be touching fufu! } \\
\text { don't remove/be removing fufu! } \\
\text { don't heat/be heating fufu! }\end{array}$ \\
\hline
\end{tabular}

\section{Appendix 10. Negative imperative plural verb forms}

Perfective AFF

\section{H+T-H}

kó ghว̀y zhá kə̄báyn ká ghว̀y lám kə̄báyn

F1
ká ghòn shítá kābáyn
ká ghày sántá kābáyn
ká ghày lé kàbáyn

ká ghòn kúm kàbáyn
Progressive AFF

\section{H+T-̀े}

ká ghว̀y á nzhíí kə̀báyn ká ghàn á nlámá kə̀báyn ká ghว̀y á nshítà kə̀báyn ká ghày á nsántà kàbáyn ká ghàn á nlèè kàbáyn ká ghày á ykùmà kə̀báyn
Gloss

don't eat/be eating fufu! don't cook/be cooking fufu! don't collect/be collecting fufu! don't sift/be sifting fufu! don't lose/be losing fufu! don't touch/be touching fufu! 


\begin{tabular}{|c|c|c|}
\hline $\begin{array}{l}\text { ká ghày shíłsá kə̄báyn } \\
\text { ká ghə̀y límsá kə̄báyn }\end{array}$ & $\begin{array}{l}\text { ká ghòy á nshìsà kə̀báyn } \\
\text { ká ghòn á nlìmsà kə̀báyn }\end{array}$ & $\begin{array}{l}\text { don't remove/be removing fufu! } \\
\text { don't heat/be heating fufu! }\end{array}$ \\
\hline 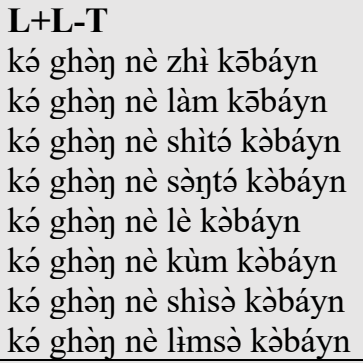 & 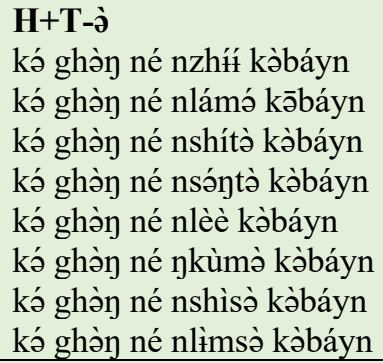 & $\begin{array}{l}\text { don't eat/be eating fufu! } \\
\text { don't cook/be cooking fufu! } \\
\text { don't collect/be collecting fufu! } \\
\text { don't sift/be sifting fufu! } \\
\text { don't lose/be losing fufu! } \\
\text { don't touch/be touching fufu! } \\
\text { don't remove/be removing fufu! } \\
\text { don't heat/be heating fufu! }\end{array}$ \\
\hline 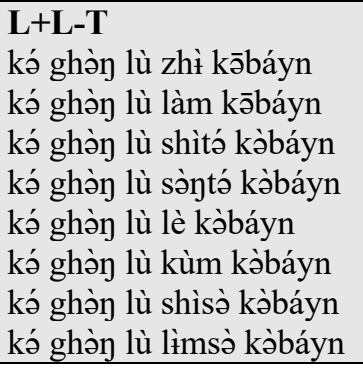 & 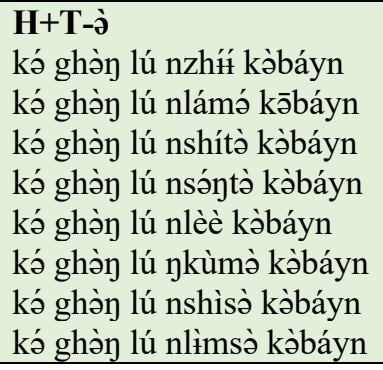 & $\begin{array}{l}\text { don't eat/be eating fufu! } \\
\text { don't cook/be cooking fufu! } \\
\text { don't collect/be collecting fufu! } \\
\text { don't sift/be sifting fufu! } \\
\text { don't lose/be losing fufu! } \\
\text { don't touch/be touching fufu! } \\
\text { don't remove/be removing fufu! } \\
\text { don't heat/be heating fufu! }\end{array}$ \\
\hline
\end{tabular}

\section{Appendix 11. Negative hortative verb forms}

Perfective AFF

H+T-H

ká yúwù zhí kābáyn ká yúwù lám kābáyn

F1 ká yúwù shítá kābáyn ká yúwù sóytá kābáyn ká yúwù lé kə̀báyn ká yúwù kúm kàbáyn ká yúwù shí sá kə̄báyn ká yúwù límsó kābáyn

\section{$\mathbf{L}+\mathbf{L}-\mathbf{T}$}

ká yúwù nè zhì kābáyn ká yúwù nè làm kābáyn ká yúwù nè shìtá kàbáyn ká yúwù nè sàntá kàbáyn ká yúwù nè lè kòbáyn ká yúwù nè kùm kàbáyn ká yúwù nè shìsò kàbáyn ká yúwù nè lìmsà kàbáyn $\mathbf{L}+\mathbf{L}-\mathbf{T}$ ká yúwù lù zh̀̀ kābáyn ká yúwù lù làm kābáyn ká yúwù lù shìtá kə̀báyn ká yúwù lù sàntá kàbáyn ká yúwù lù lè kàbáyn ká yúwù lù kùm kə̀báyn ká yúwù lù shìsà kàbáyn ká yúwù lù lìmsà kòbáyn
Progressive AFF

\section{H+T-̀े}

ká yúwù á nzhít kòbáyn ká yúwù á nlámó kə̀báyn ká yúwù á nshítว̀ kə̀báyn ká yúwù á nsántà kə̀báyn ká yúwù á nlèè kàbáyn ká yúwù á Đkùmà kàbáyn ká yúwù á nshìsà kàbáyn ká yúwù á nlìmsà kàbáyn

\section{H+T-̀े}

ká yúwù né nzhúí kàbáyn ká yúwù né nlámá kābáyn ká yúwù né nshítà kàbáyn ká yúwù né nsántว̀ kàbáyn ká yúwù né nlèè kàbáyn ká yúwù né jkùmò kàbáyn ká yúwù né nshìsà kàbáyn ká yúwù né nlìmsà kàbáyn

\section{H+T-̀̀}

ká yúwù lú nzhít kə̀báyn ká yúwù lú nlámó kābáyn ká yúwù lú nshít̀̀ kə̀báyn ká yúwù lú nsóytà kàbáyn ká yúwù lú nlèè kàbáyn ká yúwù lú ykùmò kàbáyn ká yúwù lú nshìsò kòbáyn ká ghว̀y lú nlìmsà kə̀báyn
Gloss

let's not eat/be eating fufu! let's not cook/be cooking fufu! let's not collect/be collecting fufu! let's not sift/be sifting fufu! let's not lose/be losing fufu! let's not touch/be touching fufu! let's not remove/be removing fufu! let's not heat/be heating fufu!

let's not eat/be eating fufu!

let's not cook/be cooking fufu! let's not collect/be collecting fufu! let's not sift/be sifting fufu! let's not lose/be losing fufu! let's not touch/be touching fufu! let's not remove/be removing fufu! let's not heat/be heating fufu!

let's not eat/be eating fufu! let's not cook/be cooking fufu! let's not collect/be collecting fufu! let's not sift/be sifting fufu! let's not lose/be losing fufu! let's not touch/be touching fufu! let's not remove/be removing fufu! let's not heat/be heating fufu! 


\section{Appendix 12. Negative subjunctive verb forms}

Perfective AFF

\section{H+T-H}

... lá ká yúwù zhí kə̄báyn

... lá kó yúwù lám kābáyn

F1

F2

F3

... lá ká yúwù lé kàbáyn

\section{$\mathbf{L}+\mathbf{L}-\mathbf{T}$}

$\mathbf{L}+\mathbf{L}-\mathbf{T}$
... lá ká yúwù shító kābáyn

.. lá ká yúwù sántó kābáyn

... lá ká yúwù kúm kàbáyn

... lá ká yúwù shí sá kə̄báyn

... lá ká yúwù lím`sá kābáyn

... lá ká yúwù nè zhì kābáyn

... lá ká yúwù nè làm kābáyn

.. lá ká yúwù nè shìtá kàbáyn

... lá ká yúwù nè sàntá kàbáyn

... lá ká yúwù nè lè kàbáyn

... lá ká yúwù nè kùm kàbáyn

... lá ká yúwù nè shìsà kàbáyn

... lá ká yúwù nè lìmsò kàbáyn

... lá kó yúwù lù zhì kābáyn

... lá ká yúwù lù làm kābáyn

... lá ká yúwù lù shìtó kàbáyn

... lá kó yúwù lù sòntá kàbáyn

... lá ká yúwù lù lè kàbáyn

... lá ká yúwù lù kùm kàbáyn

... lá ká yúwù lù shìsà kàbáyn

... lá ká yúwù lù lìmsò kòbáyn
Progressive AFF

Gloss

\section{H+T-̀̀}

... lá ká yúwù ó nzhí kàbáyn

... lá ká yúwù á nlámó kàbáyn

... lá ká yúwù ó nshítò kàbáyn

... lá ká yúwù á nsántà kàbáyn

... lá ká yúwù á nlèè kàbáyn

... lá ká yúwù á ykùmà kàbáyn

... lá ká yúwù á nshìsà kàbáyn

... lá ká yúwù á nlìmsà kàbáyn

H+T-̀̀

... lá ká yúwù né nzhít kàbáyn

... lá kó yúwù né nlámá kàbáyn

... lá ká yúwù né nshítò kòbáyn

... lá ká yúwù né nsóntà kàbáyn

... lá ká yúwù né nlèè kàbáyn

... lá ká yúwù né ykùmà kàbáyn

... lá ká yúwù né nshìsà kàbáyn ... lá ká yúwù né nlìmsà kàbáyn

H+T-̀̀

... lá kó yúwù lú nzhít kòbáyn

... lá kó yúwù lú nlámá kàbáyn

.. lá ká yúwù lú nshítò kàbáyn

... lá ké yúwù lú nsántò kòbáyn

... lá kó yúwù lú nlèè kòbáyn

... lá ká yúwù lú ykùmà kàbáyn

... lá kó yúwù lú nshìsò kàbáyn

... lá ká yúwù lú nlìmsò kàbáyn
... that we not eat fufu!

... that we not cook ...

... that we not collect ...

... that we not sift ...

... that we not lose ...

... that we not touch ...

... that we not remove ...

... that we not heat ...

... that we not eat fufu!

... that we not cook ...

... that we not collect ...

... that we not sift ...

... that we not lose ...

... that we not touch ...

... that we not remove ... .. that we not heat ...

... that we not eat fufu!

... that we not cook ...

... that we not collect ...

... that we not sift ...

... that we not lose ...

... that we not touch ...

... that we not remove ...

.. that we not heat ...

\section{Appendix 13. Negative future conditional verb forms}

Perfective AFF

\section{L+T-H}

sátsèn Búy dí? ká zhí kōbáyn sátsc̀n Búy dí? kó lám kə̄báyn

F1 sátsèn Búy dí? ká shító kābáyn sátsèn Bún dí? ká sántó kābáyn sátsèn Bún dí? ká lè kābáyn sátsèn Bún dí? ká kùm kābáyn sátsèn Búy dí? ká shìsá kābáyn sátsèn Bún dí? kó lìmsá kābáyn

\section{L+T-H}

sátsc̀n Bún nè dì? ká zhí kābáyn sátsc̀n Búy nè dì? ká lám kābáyn

F2 sátsc̀n Bún nè dì? ká shító kābáyn sátsèn Bún nè dì? ká sántá kābáyn sátsc̀n Bún nè dì? ká lè kābáyn sátsc̀n Búy nè dì? ká kùm kābáyn sátsc̀n Búy nè dì? ká shìsá kābáyn sátsèn Búy nè dì ká lìmsá kābáyn
Progressive AFF

\section{H+T-̀̀}

sátsc̀n Bún dí? ká nzhí kàbáyn sátsèn Búy dí? ká nlámá kàbáyn sátsèn Bún dí? ká nshítว̀ kàbáyn sátsèn Búy dí? kó nsóntò kòbáyn sátsèn Bún dí? ká nlèè kàbáyn sátsèn Bún dí? ká ykùmว̀ kə̀báyn sátsèn Bún dí? ká nshìsà kàbáyn sátsèn Bún dí? ká nlìmsà kàbáyn

\section{H+T-̀े}

sátsc̀n Búy nè dì? ká nzhút kàbáyn sátsc̀n Bún nè dì? ká nlámá kàbáyn sátsèn Bún nè dì? ká nshítà kàbáyn sátsc̀n Bún nè dì? ká nsántว̀ kàbáyn sátsc̀n Bún nè dì? ká nlèè kàbáyn sátsc̀n Bún nè dì? ká ๆkùmà kàbáyn sátsc̀n Búy nè dì? ká nshìsà kàbáyn sátsc̀n Bún nè dì? kó nlìmsò kə̀báyn
Gloss

If Bung doesn't eat fufu ... If Bung doesn't cook fufu ... If Bung doesn't collect fufu ... If Bung doesn't sift fufu ... If Bung doesn't lose fufu ... If Bung doesn't touch fufu ... If Bung doesn't remove fufu ... If Bung doesn't heat fufu ...

If Bung doesn't eat fufu ... If Bung doesn't cook fufu ... If Bung doesn't collect fufu ... If Bung doesn't sift fufu ... If Bung doesn't lose fufu ... If Bung doesn't touch fufu ... If Bung doesn't remove fufu ... If Bung doesn't heat fufu ... 


\section{L+T-H}

sátsèn Búy lù dì? kó zhé kābáyn sátsèn Bún lù dì? ká lám kābáyn

F3 sátsèn Búy lù dì? kó shító kābáyn sátsèn Bún lù dì? ká sántá kābáyn sátsčn Búy lù dì? ká lè kābáyn sátsèn Búy lù dì? ká kùm kābáyn sátsèn Búy lù dì? ká shìsá kābáyn sátsèn Bún lù dì? ká lìmsá kābáyn

\section{H+T-̀̀}

sátsc̀n Bún lù dì? ká nzhít kàbáyn sátsèn Bún lù dì? ká nlámá kàbáyn sátsc̀n Bún lù dì? ká nshítà kàbáyn sátsèn Bún lù dì? ká nsántà kàbáyn sátsèn Bún lù dì? ká nlèè kàbáyn sátsèn Bún lù dì? ká ykùmà kàbáyn sátsèn Búy lù dì? ká nshìsà kàbáyn sótsc̀n Búy lù dì? ká nlìmsà kàbáyn
If Bung doesn't eat fufu ... If Bung doesn't cook fufu ... If Bung doesn't collect fufu ... If Bung doesn't sift fufu ... If Bung doesn't lose fufu ... If Bung doesn't touch fufu ... If Bung doesn't remove fufu ... If Bung doesn't heat fufu ...

\section{Appendix 14. Negative past conditional verb forms}

Perfective AFF

\section{L+T-H}

Bún tí dì? ká 'zhá kābáyn ... Bún tí dì? ká ‘ám kābáyn ...

Bún tí dì? ká `shítá kābáyn ... Búy tí dì? ká 'sántá kābáyn ... Bún tí dì? ká lè kābáyn ... Bún tí dì? kó kùm kābáyn ... Bún tí dì? ká shìsá kābáyn ... Bún tí dì? ká lìmsá kābáyn ...

\section{L+T-H}

Bún yì tí dì? ká 'zhá kə̄báyn ... Bún yì tí dì? ká 'lám kābáyn ... Búy yì tí dì? ká `shító kə̄báyn ... Bún yì tí dì? ká ‘sántá kābáyn ... Bún yì tí dì? kó lè kōbáyn ... Bún yì tí dì? ká kùm kābáyn ... Bún yì tí dì? ká shìsá kābáyn ... Bún yì tí dì? ká lìmsá kōbáyn ...

\section{L+T-H}

Búy tò tí dì? ká 'zhá kə̄báyn ... Búy tò tí dì? ká 'lám kōbáyn ... Bún tò tí dì? ká `shítá kə̄báyn ... Bún tà tí dì? ká 'sántá kābáyn ... Bún tò tí dì? ká lè kābáyn ... Bún tò tí dì? kó kùm kābáyn ... Bún tò tí dì? ká shìsá kābáyn ... Bún tò tí dì? ká lìmsá kə̄báyn ...

\section{L+T-H}

Búy ว̀ ntí dì? ká 'zhá kābáyn ... Búy ว̀ ntí dì? ká 'lám kōbáyn ... Búy à ntí dì? ká 'shítá kābáyn ... Búy à ntí dì? ká `sántá kābáyn ... Bún ว̀ ntí dì? ká lè kābáyn ... Búy ò ntí dì? ká kùm kābáyn ... Búy à ntí dì? ká shìsá kābáyn ... Búy à ntí dì? kó lìmsó kābáyn ...
Progressive AFF

Gloss

\section{H+T-̀े}

Bún tí dì? kó nzhút kàbáyn ... Búy tí dì? ká nlámá kàbáyn ... Bún tí dì? ká nshítà kàbáyn ... Búy tí dì? ká nsántà kàbáyn ... Bún tí dì? ká nlèè kàbáyn ... Bún tí dì? ká ykùmà kàbáyn ... Búy tí dì? ká nshìsò kàbáyn ... Bún tí dì? ká nlìmsà kàbáyn ...

\section{H+T-̀े}

Bún yì tí dì? ká nzhún kàbáyn ... Bún yì tí dì? ká nlámá kàbáyn ... Bún yì tí dì? ká nshítò kàbáyn ... Bún yì tí dì? ká nsáñtà kàbáyn ... Bún yì tí dì? ká nlèè kàbáyn ... Bún yì tí dì? ká ykùmà kàbáyn ... Bún yì tí dì? ká nshìsà kàbáyn ... Bún yì tí dì? ká nlìmsà kàbáyn ... H+T-̀̀

Búy tò tí dì? ká nzhút kàbáyn ... Bún tò tí dì? ká nlámá kàbáyn ... Bún tò tí dì? ká nshítà kàbáyn ... Bún tò tí dì? ká nsántà kàbáyn ... Bún tò tí dì? kó nlèè kàbáyn ... Bún tò tí dì? ká ykùmà kàbáyn ... Búy tò tí dì? ká nshìsò kàbáyn ... Bún tà tí dì? ká nlìmsà kàbáyn ...

\section{H+T-̀े}

Búy ò ntí dì? ká nzhúk kàbáyn ... Búy à ntí dì? ká nlámá kàbáyn ... Bún ̀̀ ntí dì? ká nshítà kàbáyn ... Bún ว̀ ntí dì? ká nsántà kàbáyn ... Búy ว̀ ntí dì? ká nlèè kàbáyn ... Búy ว̀ ntí dì? ká ykùmà kàbáyn ... Bún à ntí dì? ká nshìsà kàbáyn ... Bún ว̀ ntí dì? ká nlìmsà kàbáyn ...
If Bung hadn't eaten fufu .... If Bung hadn't cooked fufu ...! If Bung hadn't collected fufu ...! If Bung hadn't sifted fufu ...! If Bung hadn't lost fufu ...! If Bung hadn't touched fufu ...! If Bung hadn't removed fufu ...! If Bung hadn't heated fufu ...!

If Bung hadn't eaten fufu ...! If Bung hadn't cooked fufu ...! If Bung hadn't collected fufu ...! If Bung hadn't sifted fufu ...! If Bung hadn't lost fufu ...! If Bung hadn't touched fufu ...! If Bung hadn't removed fufu ...! If Bung hadn't heated fufu ...!

If Bung hadn't eaten fufu ...! If Bung hadn't cooked fufu ...! If Bung hadn't collected fufu ...! If Bung hadn't sifted fufu ...! If Bung hadn't lost fufu ...! If Bung hadn't touched fufu ...! If Bung hadn't removed fufu ...! If Bung hadn't heated fufu ...!

If Bung hadn't eaten fufu ...! If Bung hadn't cooked fufu ...! If Bung hadn't collected fufu ...! If Bung hadn't sifted fufu ...! If Bung hadn't lost fufu ...! If Bung hadn't touched fufu ...! If Bung hadn't removed fufu ...! If Bung hadn't heated fufu ...! 


\section{References}

Akumbu, Pius W. 2008. Kejom (Babanki)-English lexicon. Köln: Rüdiger Köppe Verlag.

Akumbu, Pius W. 2011. Tone in Kejom (Babanki) associative constructions. Journal of West African Languages 38(1). 69-88.

Akumbu, Pius W. 2015. Babanki verb tone. Studies in African Linguistics 44(1). 2-26.

Akumbu, Pius W. 2016. Babanki coda consonant deletion and vowel raising: A case of allomorphy. Berkeley Linguistics Society (BLS) 42. 3-20.

Akumbu, Pius W. 2019. A featural analysis of mid and downstepped high tone in Babanki. In Emily Clem, Peter Jenks \& Hannah Sande (eds.), Theory and description in African linguistics: Selected papers from the 47th Annual Conference on African Linguistics. 3-20. Berlin: Language Science Press.

Akumbu, Pius W. \& Evelyn Fogwe Chibaka. 2012. A pedagogic grammar of Babanki. Köln: Rüdiger Köppe Verlag.

Akumbu, Pius W. \& Larry M. Hyman. 2017. Nasals and low tone in Grassfields noun class prefixes. Nordic Journal of African Studies 26(1). 1-13.

Anderson, Stephen C. 1979. Verb structure. In Larry M. Hyman (ed.), Aghem grammatical structure. 73136. Los Angeles: Department of Linguistics, University of Southern California.

Chie, Esther P. 2014. The phrasal phonology of Gá?á Kàdż̀m (Babanki): An outgrowth of the other components of the grammar of the Language. Yaoundé, CR: University of Yaoundé I dissertation.

Hyman, Larry M. 1979. Tonology of the Babanki noun. Studies in African Linguistics 10. 159-178.

Hyman, Larry M. 1980. Babanki and the Ring group. In Larry M. Hyman \& Jan Voorhoeve (eds.), Noun classes in Grassfields Bantu. 225-258. Paris: SELAF.

Hyman, Larry M. 2016. Morphological tonal assignments in conflict: Who wins? In Enrique Palancar \& Jean Léo Léonard (eds.), Tone and inflection: New facts and new perspectives. 15-39. Berlin/Boston: De Gruyter Mouton.

Hyman, Larry M. 2018. Common Bantoid verb extensions. In John R. Watters (ed.), East Benue-Congo: Nouns, pronouns, and verbs. 173-198. Berlin: Language Science Press.

Hyman, Larry M. \& John R. Watters. 1984. Auxiliary focus. Studies in African Linguistics 15. 233-273.

Inkelas, Sharon. 2011. The interaction between morphology and phonology. In John A. Goldsmith, Jason Riggle \& Alan C. L. Yu (eds.), Handbook of phonological theory, 2nd edition. 68-102. Hoboken, NJ: Wiley-Blackwell.

Inkelas, Sharon \& Cheryl Zoll. 2007. Is grammar dependence real? A comparison between cophonological and indexical approaches to morphologically conditioned phonology. Linguistics 45. 133-171.

Meeussen, A. E. 1967. Bantu grammatical reconstructions. Africana Linguistica 3. 79-121. Tervuren: Musée Royal de l'Afrique Centrale.

Mutaka, Ngessimo M. \& Esther Phubon Chie. 2006. Vowel raising in Babanki. Journal of West African Languages 33. 71-88.

Van der Wal, Jenneke \& Larry M. Hyman (eds.). 2017. The conjoint/disjoint alternation in Bantu. Berlin: De Gruyter Mouton.

Watters, John Robert. 1979. Focus in Aghem: A study of its formal correlates and typology. In Larry M. Hyman (ed.), Aghem grammatical structure. 137-197. Los Angeles: Department of Linguistics, University of Southern California.

Pius W. Akumbu

Department of Linguistics

University of Buea

P.O Box 63

Buea, Cameroon akumbu.pius@ubuea.cm
Larry M. Hyman

Department of Linguistics

1203 Dwinelle, MC 2650

University of California

Berkeley, CA 94720-2650

hyman@berkeley.edu
Roland Kießling

Department of Asia-Africa Studies

Universität Hamburg

Edmund-Siemers-Allee 1

20146 Hamburg, Germany

roland.kiessling@uni-hamburg.de 